ANUARIO DE Estudios MEDIEVALES

46/1, enero-junio de 2016, pp. 231-268

ISSN 0066-5061

doi:10.3989/aem.2016.46.1.07

\title{
... QUE NOS TENEMUS A DICTO DOMINO REGE PRO CAMERA ASSIGNATA. THE DEVELOPMENT, ADMINISTRATION AND SIGNIFICANCE OF THE QUEENLY ESTATE OF ELIONOR OF SICILY (1349-1375) ${ }^{1}$
}

\author{
... QUE NOS TENEMUS A DICTO DOMINO REGE PRO \\ CAMERA ASSIGNATA. DESARROLLO, ADMINISTRACIÓN \\ $Y$ SIGNIFICADO DE LOS BIENES REGINALES \\ DE LEONOR DE SICILIA (1349-1375)
}

\author{
SEBASTIAN ROEBERT \\ Universität Leipzig / Universitat de Barcelona
}

\begin{abstract}
Queens dowries were of central importance for their capacity of action. So far, however, they have not been studied extensively or comparatively. The case of queen Elionor of Sicily, wife of Peter IV the "Ceremonious", allows a detailed reconstruction of the development and functions of her estate based on a wide documentary corpus which has not yet been analysed systematically. Also the concrete administration of her domain can be reconstructed very precisely in this particular case, allowing us to determine its position and functions within the framework of the monarchy as well as the agency of the queen.
\end{abstract}

Keywords: Crown of Aragon; 14th century; queens; queenship; Elionor of Sicily; dowry.
Resumen: Los bienes dotales de una reina eran de una importancia fundamental para determinar su margen de acción. Pese a ello, no disponemos de estudios sistemáticos y comparativos al respecto. El caso de la reina Leonor de Sicilia, esposa de Pedro IV el Ceremonioso, permite la reconstrucción detallada del desarrollo y de las funciones de su patrimonio sobre la base de un amplio corpus documental que no ha sido analizado hasta ahora. A partir de él, se puede también analizar claramente cómo se desarrolló la administración concreta de su patrimonio en este caso particular. De esta manera, se pueden determinar las funciones concretas dentro del sistema de la monarquía y, por lo tanto, también el margen de acción reginal.

Palabras claves: Corona de Aragón; siglo XIV; reinas; Leonor de Sicilia; dote.

${ }^{1}$ Abbreviations: ACA = Arxiu de la Corona d'Aragó; AHN = Archivo Histórico Nacional; $\mathrm{C}=$ Cancelleria; carp. = carpeta; $\mathrm{MR}=$ Mestre Racional; perg. = pergamins; reg. = register; $\mathrm{RP}=$ Arxiu del Reial Patrimoni. All cited registers are from the ACA, section Cancelleria. The Arabic number in square brackets indicates the number of the register entry on the folio. The toponyms have been used as follows: for Catalonia, València and the Balearic Islands in Catalan, for Aragon in Spanish and the Roussillon in French. I would like to thank to Thomas Smith and Duane Henderson for the revision of the text and to Stefano Cingolani for his helpful comments. 


\section{SUMMARY}

1. Introduction.- 2. Development of Elionor's goods until 1368.- 3. Revision of the estate in 1368 and further modifications.- 4. Cooperation and competition: administration of the queenly domain.- 5. Conclusions.- 6. Bibliography.- 7. Appendices.

\section{INTRODUCTION}

Despite recent studies on medieval queens and their agency, the development and administration of the queenly dos has not yet been analysed sufficiently. While this subject has been analysed in some depth for earlier periods, the later Middle Ages have been studied less intensively. Furthermore, there has been no comparative analysis of the development of the queen's estate $^{2}$. This is a significant hiatus, since the nature of the dowry seems to have changed in the course of the high Middle Ages: during this time, the dynasty gained importance over the individual, reducing the queen's control over her goods to a mere usufruct ${ }^{3}$. Despite these restrictions, the dowry still could serve as the basis for the queens to pursue an independent policy ${ }^{4}$. With this material foundation, queens were able to carry out actions in all political fields, even including military activities ${ }^{5}$. To preserve this capacity, it was essential to keep the queenly domain together and to control it. The queen's domain was not firmly established but depended on the personal relation between the monarchs; it could be endangered by changes of government following the death of the queen's husband ${ }^{6}$ as shows the example of Leonor of Castile (1307-1358) after the death of Alphonse IV (1327-1366). The prospective value of the marriage was also a factor in determining the endowment of the queen-to-be ${ }^{7}$.

The marriage between Peter IV of Aragon, the "Ceremonious" (1336-1387), and Elionor of Sicily in 1349 was valued very highly, since it entailed the possibility of increasing Aragonese influence in Sicily. We might expect Elionor's dowry, therefore, to have been considerable. Despite

\footnotetext{
${ }^{2}$ See Fößel 2005, pp. 25-26. For earlier phases in Catalonia/Crown of Aragon and the Iberian Peninsula, see Aurell 2002; Clay 1993. In Sicily, the domain of the queen (camera reginale) has received continuous scholarly attention since the 19th century; see Orlando 2012, pp. 113-114 for Syracuse.

${ }^{3}$ Aurell 2002, pp. 179-182; Jaspert 2015, pp. 103-104.

${ }^{4}$ Earenfight 2013, pp. 178, 203-204; Bianchini 2012, pp. 4, 46; Earenfight 2010a, pp. 5-6; Silleras 2010, pp. 76-78; Rodrigues, Santos 2010, pp. 210-211; Fößel 2005, p. 45.

${ }^{5}$ Rodrigues 2007, pp. 11-12.

${ }^{6}$ Fößel 2005, p. 45; Brown 2000, pp. 159-163; Silleras 2010, pp. 79-81.

${ }^{7}$ Orlando 2012, p. 131.
} 
its significance, however, this case has not yet been studied. Salvatore Fodale analyses the marriage negotiations and the initial endowment of Elionor -without considering her possible participation in the negotiations ${ }^{-}{ }^{8}$. Ulla Deibel provides a survey of the queenly goods, but her perspective is selective rather than systematic ${ }^{9}$. Mark Meyerson studies the administration of the Jewish aljama of Morvedre and the queen's motivation for protecting it. He concludes that the principal reason for the protection of the Jewish community by Elionor of Sicily and Maria de Luna was the preservation of its economic potential, thus maintaining an important source of income for the monarchy ${ }^{10}$. Both queens carried out this policy with success, especially Elionor, whose measures restored the aljama after the War of the Two Peters (1356-1366) ${ }^{11}$. The present article analyses the development of Elionor of Sicily's goods and their administration offering an insight into the function of the queenly goods in the framework of the monarchy as a cooperative institution ${ }^{12}$.

The case of Elionor of Sicily is suitable for a broadly based empirical examination of queenly dowry, drawing particularly on the, particularly the chancery registers in the Crown of Aragon Archives which have not yet been analysed systematically ${ }^{13}$. The development of the queen's domain can be traced accurately in the four volumes of chancery registers Pro Regina Elionore (ACA, C, reg. 1534-1537). The first and last volumes (ACA, C, reg. 1534 and 1537) cover her entire reign (i.e. 1349-1375) and even contain some documents issued after the queen's death. Besides the administration of the domain they also contain documentation and correspondence concerning the marriage negotiations with Sicily and the fulfilment of the testament. These two volumes are the original registers which were kept continuously and in chronological order. The documents in reg. 1534 date mostly between 1349 and 1361, while reg. 1537 covers Elionor's entire reign ${ }^{14}$. With one exception, these volumes contain no duplicate documentation. The two other registers (1535 and 1536) date from 1368 and mainly record the development of

\footnotetext{
${ }^{8}$ Fodale 2012, see pp. 44-47 about the dowry.

${ }^{9}$ Deibel 1928, pp. $429-437$.

${ }^{10}$ Meyerson 2005, pp. 55-56; economic interests dominated also in the case of Isabel of Castile, even after the expulsion of the Jews, $c f$. Zeldes 2004, p. 74. 2012.

${ }^{11}$ About this war and especially its repercussions on the kingdom of Aragon see Lafuente

${ }^{12}$ Earenfight 2013,pp. 24-27; Bianchini 2012, p. 7.

${ }^{13}$ ACA, C, reg. 1563-1585. The records of the Mestre Racional for Elionor of Sicily are also preserved in the ACA (with a few volumes missing) but cannot be included in the present study.

${ }^{14}$ See fig. 1.
} 
Elionor's domain up to this moment ${ }^{15}$. Together, they contain 110 documents many of which are duplicates. However, the two volumes differ greatly in some aspects and complement each other. Reg. 1535 concerns mostly the beginnings of the administration of the queen's domain in 1349, while reg. 1536 records subsequent documentation ${ }^{16}$. Taken together, all four registers make it possible to reconstruct the queenly dowry, as far as it pertains to the royal domain, and to examine the ups and downs of the queenly domain of Elionor of Sicily in detail ${ }^{17}$. Since in most other European regions the source basis for such a study is scarce or even virtually inexistent, the results of this case study (and other possible studies based on the documentation of the Crown of Aragon) might have a much broader relevance for other European regions and could serve as reference for a comparative study of the subject of queenly dowry ${ }^{18}$.

\begin{tabular}{|c|c|c|}
\hline VOLUME & PERIOD COVERED & $\begin{array}{c}\text { NUMBER } \\
\text { DOCUMENTS }\end{array}$ \\
\hline 1534 & 1348 November 2 - 1361 December 28 & 309 \\
\hline 1369 & February 28 - 1376 February 17 & 26 \\
\hline 1537 & 1349 September 28 - 1377 January 26 & 206 \\
\hline 1535 & 1349 August 27 - 1368 August 11 & 48 \\
\hline 1536 & 1349 September 27 - 1368 August 11 [1373 May 27] ${ }^{19}$ & 62 \\
\hline
\end{tabular}

Fig. 1. The Registers Pro Regina Elionor.

${ }^{15}$ Only four documents date from the time after 1368: ACA, C, reg. 1536, f. 89r [1], Sant Mateu del Maestrat, 1370 Feb. 20; f. 89v [1], Sant Mateu del Maestrat, 1370 Feb. 14, f. 90v [1], València, 1371 July 8 and f. 92v [1], Barcelona, 1373 May 27.

${ }^{16}$ ACA, C, reg. 1535 is missing f. 40 and due to the critical condition of reg. 1534,1535 and 1537, several documents are at least partially illegible. Therefore, duplicated documents are cited after reg. 1536.

${ }^{17}$ Other negotiations were not taken into account, see below, part 3 for Molins de Rei and Sabadell.

${ }^{18}$ Cf. Jaspert 2015, pp. 123-124.

${ }^{19}$ Four documents were added afterwards; they date between 1370 and 1373 . 


\section{DEVELOPMENT OF ELIONOR's GOODS UNTIL 1368}

The amount of Elionor's dowry can be reconstructed primarily from 19 documents which date from between 1349 and 1373. As initial dotation, Elionor should have received Tarazona, Teruel and Jaca with Candanchú in Aragon, and Collioure and Thuir in Roussillon, with an income of 10,000 Barcelonese pounds $(200,000 \text { solidi })^{20}$. Apparently, the income from the assigned places was insufficient, since the list of places actually transferred by the king to his wife in fact additionally included Canfranc and the marketplace of Biescas near Jaca, as clarified by the dotation-charter from 27 September $1349^{21}$. However, the total income of 10,000 Barcelonese pounds remained the same. The concept of a coherent queenly domain can already be found at this point because the same properties had already been possessed before by preceding queens. Elionor of Sicily was to own the domain with the same conditions as her predecessors and to receive it free from any obligations ${ }^{22}$.

Elionor was guaranteed tax sovereignty, while the king renounced his right allowing her to tax the Jewish and Muslim aljamas which would be free from other taxes. The inhabitants were obliged to swear loyalty to Elionor and her officials (homagium et fidelitatis iuramentum). Peter IV also guaranteed the income of the domain, should it be diminished, for instance as a consequence of war, promising her to substitute the losses from his own goods. A solemn dotation charter was issued in duplicate -one copy was to remain with the king and the other one with the queen- ${ }^{23}$. There is explicit mention of two separate courts of the king and the queen respectively. Therefore, Elionor maintained an independent and fully functional household since the beginning of her reign. Furthermore, another function of her court, or at least her chambers, can be traced in this diploma: it served as a centre of

\footnotetext{
${ }^{20}$ See the report of the envoys Galceran de Bellpuig and Llop de Gurrea about the negotiations in ACA, C, reg. 1535, f. 1r [1], here f. 6r. The first five folia are in very critical condition so that many aspects of this detailed report cannot be understood; on the modifications of the dowry see Appendix table 1.

${ }^{21}$ ACA, C, reg. 1534, f. 12r [1] = reg. 1535, f. 12r [1] = reg. 1536, f. 1r [1].

${ }^{22}$ ACA, C, reg. 1536, f. 1v: "que omnia teneatis, habeatis et possideatis et recipiatis integriter et complete, prout melius et pinguius nos et predecessores vestri (Sic) tenere consuevimus aut prout perfectius preterite Regine Aragonum tenere consueverunt dictas civitates, castra vel alia loca eis pro camera seu dodario assignata"; on f. $2 \mathrm{v}$ the two previous spouses of Peter IV, Maria of Navarra and Leonor of Portugal, are mentioned as anterior proprietors of the places.

${ }^{23}$ Furthermore, the importance of this diploma is emphasized by two other aspects: first, the king swore not only by the Gospels as customary but also by the Holy Cross and, second, it was attested by at least eleven witnesses (ibidem, f. 4r). In accordance with the Ordinacions of Peter IV, a privilege should be witnessed by the five noblest persons present at the court, Gimeno et al.2009, p. 125.
} 
political decisions -the charter was issued in Elionor's chambers in the royal palace in València $-{ }^{24}$.

Because of the high mortality due to the Plague the domain as stipulated on 27 September 1349 could not produce its anticipated income ${ }^{25}$. For this reason, Peter IV complemented the revenue of his spouse by contributions from the Jewish aljamas of Barcelona, València, Lleida, Girona, Besalú, Cervera and Vilafranca del Penedès as well as Borja for a total of 60,000 solidi $^{26}$. For the same reason, one year later, Elionor received the revenues of the ports of Menorca and Eivissa ${ }^{27}$. Out of gratitude for the birth of the firstborn son, John (later John I, 1387-1396), Peter IV donated the revenues of Le Boulou and Montesquieu in Roussillon to Elionor on the occasion of the Circumcision of Christ in 1351 celebrated in Perpignan ${ }^{28}$. She was to possess these under the same conditions as Thuir ${ }^{29}$.

At the beginning of 1350, the king conferred Biota and El Bayo to his spouse. Previously these places had belonged to Juan Ximénez de Urrea, but they had been confiscated for crimes against the crown because of his participation in the Union of Aragon ${ }^{30}$. However, the grant to Elionor contained a clause reserving Peter's rights. After the birth of two sons and their survival (without any temporal specification) both towns were to revert to the king ${ }^{31}$.

${ }^{24}$ ACA, C, reg. 1536, f. 4r: "que fuerunt acta in camera dicte domine Regine regalis regii civitatis Valencie (sic)". See Jaspert 2015, pp. 101-102 for the queenly palace as "familiäres Pendant" to the royal palace in its function as power centre.

${ }^{25}$ ACA, C, reg. 1536, f. 5r [1]: "cum sint propter mortalitates pestiferas nunc elapsos et alias a valore solito minorati, ad ipsas decem mille libras Barchinonensium (...) non ascendunt". About the effects of the Plague see Vilar 2001, pp. 214-216. More recent investigations differentiate its consequences; see Furió, García-Oliver 2007, pp. 248-255; Sabaté 2015, pp. 80-83.

${ }^{26}$ ACA, C, reg. 1535, f. 16r [1] = reg. 1535, f. 16v [1] = reg. 1536, f. 5r [1], València, 1349 November 13.

${ }^{27}$ ACA, C, reg. 1534, f. 41r [1] = reg. 1535, f. 27r [1] = reg. 1536, f. 11r [1], Perpignan, 1350 November 18.

${ }^{28}$ ACA, C, reg. 1534, f. 45v [1] = reg. 1535, f. 29r [1] = reg. 1536, f. 68r [1] (cited): "debita meditatione pensantes quod sicuti nostris obsequiis inherentes premio retributionis frequenter prosequimur universos dignius reputamus et congruentius arbitramur ut vos, illustris Alionora Regina Aragonum, carissima consors nostra, que tanquam pars nostri corporis nobis servire attentius servitiis placidiis ceteris omnibus anelatis, a nobis promptius assequamini gratiam pinguiorem. Ideo hiis inducti et quia respectu gratie affluentis et donationis inmense nobis factarum de diutius primogenito expectato nobis et vobis comuni noviter nato divinitus reputamus".

${ }^{29} \mathrm{ACA}, \mathrm{C}$, reg. 1536, f. 68r: "habendas et tenendas atque pacifice possidendas toto tempore vite vestre (...) cum illis universis et singulis titulis, iuribus et redditibus, vocibus, conditionibus atque pactis et aliis quibuscumque, quibus et sub quibus locum de Tuhirio vobis dedimus (...), prout in cartis donationis per nos vobis facte de dicto loco de Tuhirio (...) continetur".

${ }^{30}$ ACA, C, reg. 1534, f. 28r [1] = reg. 1535, f. 21r [1], València, 1350 January 1.

${ }^{31} \mathrm{ACA}, \mathrm{C}$, reg. 1535, f. 22r: "Retinemus tamen nobis quod, quan[do]cumque post primogenitum filium nostrum masculum, quem a vobis Dei mediante (...) speramus, filium masculum 
Yet, before the birth of the second son, Martin (Martin I, 1396-1410), Peter IV exchanged both places against Duesaigües, Guadelest, Madrona, Millares, Caves, El Puig de Santa Maria and Penàguila in the kingdom of València ${ }^{32}$. Once again, the diploma limits the possession of the goods to the birth of male progeny, or rather the expected birth of a second son.

Prince Ramon Berenguer, count of Empúries, and his wife Maria Álvarez de Xèrica (Maria Alvari), who was acting as tutor for their common son Prince John, sold the town and castle Llíria in València on 16 May 1354 in free property to Elionor (allodium franchum) ${ }^{33}$. The count had purchased the town on 6 October 1340 for 11,500 Barcelonese pounds cum instrumento gratie, through which the monarch could re-acquire the possessions ${ }^{34}$. This stipulation was included in the donation to Elionor, meaning that the town was not permanently her possession. Probably due to this restriction, a royal confirmation of the purchase was necessary, and Peter IV issued it before leaving for Sardinia in order to subdue the rebellion of the Judge of Arborea. The purchase price of 407,000 Barcelonese solidi agreed to by Elionor and the count of Empúries was considerably higher than the price for which he had originally acquired the town. In the event of the re-acquisition of Llíria by the king, the count was to refund the difference to the queen ${ }^{35}$. Elionor also redeemed several towns and villages of the county which Malgaulí (Ponç VI), the last count of Empúries from the original dynasty, had pawned to pay the dowry for his wife Isabella, a daughter of Frederick II (III) of Sicily (and therefore an aunt of Elionor) ${ }^{36}$.

secundo genitum sucepimus incontinenti ipsis tamen primogenito et secundogenito viventibus predicta que vobis damus nobis pleno iure integre devolvantur".

${ }^{32}$ ACA, C, reg. 1534, f. 82v [1] = reg. 1535, f. 33r [1] = reg. 1536, f. 19r [1], València, 1353 January 27.

${ }_{33}$ ACA, C, reg. 1536, f. 23r [1], Barcelona, 1354 May 16. The royal confirmation in reg. 1534, f. 104r [1], Roses, 1354 June 8.

${ }^{34}$ On the form of the carta de gràcia see Ferrer i Mallol 1970-1971, pp. 367-370.

${ }^{35}$ ACA, C, reg. 1536, f. 27v: "si dictus dominus Rex pretextu carte gratie (...) vellet luere seu redimere castrum et villam predictam de Liria et in dicto casu ipse dominus Rex non teneretur vobis restituere seu dare tantam peccunie quantitatem quanta est quantitas, pro qua vobis, dicte domine Regine, ego nominibus predictis iuxta dictam compositionem castrum et villam predicta de Liria vendo sive do et concedo in solutum predictorum, ut prefertur. Eo casu dictus dominus infans et dicta domina comitissa nomine tutorio predicto vobis (...) de ea dumtaxat teneantur quantitate, quam dictus dominus Rex vobis minus restituere sive dare teneretur, facto scilicet computo per magistrum rationalem curie dicti domini Regis super quantitatibus, quas dictus dominus infans habeat in et super castro et villa de Liria predictis, cuius magistri rationalis computo uterque pars stare teneatur iuxta compositionem predictam".

${ }^{36} \mathrm{Ibidem}$, f. $29 \mathrm{v}$ : "donamus, absolvimus, difinimus, remitimus et relaxamus (...) dictis etiam inclitis comiti et comitisse Impurie ac dicto egregio Johanni, eorum filio, et suis et quibus velint perpetuo proprietatem et dominium castrorum et villarum predictorum de Impuriis, de Bellcayre, de Occulostricto, de Sancto Petro Piscatore et de Siurana in dicto comitatu Impurie situatorum, pro dictis dote et lucro nuptiali dicte nobilis Isabelle, ut predicitur, obligatorum". 
A series of donations began four years later, which were executed between 1358 and 1366 and must be considered in the context of the events during the war against Castile. From the pawned goods of the countess of Terranova, Elionor redeemed several places in the kingdom of Valencia: Alcoi, Barxell, Gorga, Travadell and Xirillent. In return for the redemption of these towns, Peter IV assured Elionor their possession for her lifetime. In the event of her death, however, the goods in question were to return to the crown entirely. The donation to Elionor was justified by the special marital relation guaranteeing that the goods would not fall into foreign hands because the royal couple was considered to be of one flesh ${ }^{37}$. Therefore the queenly domain could be considered as an extension of the royal patrimony; or rather that both possessions formed a unit. In autumn 1358 the king donated the castle of Montcada with all its revenues at his will (dum nobis placuerit or ad nostrum beneplacitum) to his spouse. This donation was made twice: on 23 of September and again on 10 of October $^{38}$. Their contents differ in two key aspects. The first version refers to the nullification of a rent (violarium) which Peter IV had bestowed upon Gonçal de Castellvell in 1348. The king compensated him by conferring on him an alcaydia in the kingdom of Valencia. This reference is missing in the second version, where the oath of loyalty to be rendered by the inhabitants of Montcada is highlighted. More important is the motivation to issue the second version which was that the transfer of the castle to the queen's dominion guaranteed a greater chance to preserve the goods for the heirs ${ }^{39}$. The queen therefore occupied a central role in preserving the economic basis of the monarchy. Her dominion was secure because -in contrast to the princes- she could not alienate goods of the royal domain.

Especially important for the development of the queen's domain was the donation of revenues of the assassinated stepmother of Peter IV,

${ }^{37}$ ACA, C, reg. 1534, f. 118v [2] = reg. 1535, f. 47r [1], Girona, 1358 July 28; reg. 1534, f. 119r: "pensantes necminus quod sicut Altissimus nos et vos unam carnem esse voluit, sic ea que vobis damus nobis utique retinemus et quod emolumentum et comodum dictorum castrorum et locorum quod non modici valoris existit ad alienas manus perveniens nunc et quamdiu ipsa duraret pignoratio deinceps facta, ipse redemptione spectabit ad vos, dictam Reginam, et per consequens ad nos, cum simus, ut predicitur, una caro".

${ }^{38} \mathrm{ACA}, \mathrm{C}$, reg. 1534, f. 122r [2] = reg. 1535, f. 49r [1] = reg. 1536, f. 38r [1], Barcelona, 1358 September 23; ACA, C, reg. 1534, f. 149v [1] = reg. 1536, f. 39v [1], Barcelona, 1358 October 10.

${ }^{39}$ ACA, C, reg. 1536, f. 39v: "dum merita assignata vestri, illustris Alienore Regine Aragonum, consortis nostre karissime, accendimus dumque vestra placibilia obsequia intra nos debita meditatione pensamus dignum valde reputamus et congruum, ut vos, dicta Regina, nostris donis atque gratiosis favoribus pre ceteris decoremus potissime cum ea, que vobis conferimus, non a nobis speramus, set nostris heredibus potius conservemus". 
Leonor of Castile ${ }^{40}$. Due to the wars against Genoa and Castile, the revenues of Tarazona, the Jewish aljamas of Borja and Vilafranca del Penedès, the coin of Jaca and the lezda of Collioure had suffered severe losses. Peter IV was therefore obliged to compensate his spouse according to the original dotation. On 27 April 1359 he donated Alzira, Morella, Morvedre and Xàtiva (kingdom of Valencia) and Calatayud and Huesca (Aragon) $)^{41}$. Further, on 20 February 1360, Peter IV gave the revenues of Montblanc, Tàrrega and Vilagrassa, all revenues from civil and criminal jurisdiction, and the revenues of the Jewish and Muslim aljamas in return for the revenues of the aljamas of Besalú, Cervera, Girona and Vilafranca del Penedès, which Prince John received instead. With this change, the king wanted to express his gratitude to his spouse without further specifying this motive. Probably his thanks referred to her actions as royal lieutenant in 1359, while Peter IV himself was in Mallorca fighting the Castilian fleet. Only a short time before, Montblanc, Tàrrega and Vilagrassa had been returned to Peter IV by count Henry of Trastámara, the later King Henry II of Castile and at this point Aragonese ally in the war against Castile. In his donation to Elionor, Peter made the proviso that he might confer these properties once again on the count of Trastámara, and in such an event he assured his wife a compensation of the same amount of revenues from other properties $^{42}$. Montblanc, Tàrrega and Vilagrassa also originated from the domain of Eleanor of Castile. Both donations conferred on Elionor the right to appoint the baiulus of the towns, following the royal provisions made to her predecessors. Peter IV arranged that copies of the relevant documents be handed over to the queen.

She did not possess Montblanc, Tàrrega and Vilagrassa for a long time, because they were restituted, with her approval, to Henry of Trastámara in December 1362 after the counsel of the Corts of Monzón. In return she received the revenues from the Albufera of València and rent revenues from the Jewish aljama of Barcelona ${ }^{43}$. One week later, Peter IV added the incomes

${ }^{40}$ The donation was carried out twice, on 27 April 1359 in Barcelona (ACA, C, reg. 1536, f. 42r [1]) and on 12 September 1359 (ibidem, f. 44r [1]). On Leonor of Castile see RecueroLista 2013, Baydal 2011, p. 225. The possessions which Alphonse IV transferred to her caused much discontent among the Valencians, cf. Baydal 2013, p. 19 and pp. 46-65 (with a systematic and critical analysis of the donations to Leonor of Castile based on the accounts of Peter IV and Zurita as well as the documentation from the royal chancery).

${ }^{41}$ ACA, C, reg. 1534, f. 151r [6] = reg. 1536, f. 42r [1]: "ex conditione et conventione inter nos et vos inita habente quod si ratione guerrarum seu quovis alio casu redditus et iura predicta per nos vobis pro camera assignata quandocumque et quomodocumque detrimentum seu diminutionem susciperent".

${ }^{42}$ ACA, C, reg. 1534, f. 142v [1] = reg. 1536, f. 45r [1], Zaragoza, 1360 February 20.

${ }^{43}$ ACA, C, reg. 1537, f. 49r [1] = reg. 1536, f. 50v [1], Monzón, 1362 December 20. 
of the salt works of València and another week afterwards he renewed the donation of the city's Jewish aljama ${ }^{44}$.

Shortly after the execution of the Infant Ferran, stepbrother of Peter IV and marquis of Tortosa, on 16 July 1363, Elionor received several properties from his domain and among them Tortosa, the principal town of the marquisate ${ }^{45}$. This step was taken to compensate for the loss of several towns and villages in Aragon and Valencia which had been occupied by Peter I of Castile: Tarazona, Teruel and its villages, Calatayud, Borja, Morvedre, Llíria and El Puig de Santa Maria ${ }^{46}$. As a consequence, the queenly incomes had depreciated in such a manner that she hardly possessed the means to maintain her familia. This donation did not become effective immediately, however, because the widow of Ferran, Maria of Portugal, had to be compensated for the loss of her dowry. This process dragged on until June 1373 and proved costly for the monarchs, who agreed to pay a compensation of 60,000 florins to Maria of Portuga ${ }^{47}$. Elionor contributed 10,000 florins to this sum and was to receive several properties from the Infanta in return which already had been transferred ten years before ${ }^{48}$.

After the death of Elisenda de Montcada, widow of James II and founder of Pedralbes, Elionor received from her domain the rights in Tortosa. Additionally, Peter IV conferred Berga, Borriana, Pals and Torroella de

${ }^{44}$ ACA, C, reg. 1537, f. 50r [1] = reg. 1536, f. 54r [1], Monzón, 1362 December 29; cf. Hinojosa 2007, p. 61; ACA, C, reg. 1537, f. 53r [1] = reg. 1536, f. 55r [1], Monzón, 1363 January 8 (ed. Hinojosa 2007, no. 69, appendix pp. 66-70).

${ }^{45}$ ACA, C, reg. 1537, f. 58v [1] = reg. 1536, f. 71v [1], Mequinensa, 1363 July 28: in Catalonia: Alòs (castle), Camarasa (castle), Cubells (castle), Igualada, Llimiana, Llorenç de Montgai (castle), Santa Linya, Vilanova de Meià (castle), Montgai, Tortosa; in València: Ảsp, Alacant, Callosa, Elda, Guardamar, La Mola, Nonpot, Novelda, Oriola; in Aragón: Albarracín, Ballobar and Fraga with several villages, see Cantarell, Comas 2002, p. 562. All places came to the braç reial, cf. Sánchez 2005, pp. 150-151. At least Asp, Elda and Novelda had already belonged to the Crown after the Sentence of Torrellas in 1305, Ferrer i Mallol 1988, pp. 2-3.

${ }^{46}$ For the occupation, see Soldevila 1963, pp. 470-471; Lafuente 2012, p. 109; on the posthumous conviction of Ferran, see ibidem, pp. 123-128. Some places, among them Calatayud, Morvedre and Teruel, were destined in the treaty of Morvedre of 1363 as dowry for the planned wedding between the Castilian Infant John and the oldest daughter of Peter IV and would have been lost to Elionor's domain in case of the realisation of the marriage, $c f$. Soldevila 1963, p. 472; Lafuente 2012, p. 113.

${ }^{47}$ The details cannot be discussed here; the agreement between Peter IV and Elionor with Maria of Portugal ed. Madurell 1971, pp. 430-437 following the copy of the notary Francesc de Ladernosa in the Arxiu Històric de Protocols in Barcelona, another copy in reg. 1581, f. 139v [3], Barcelona, 1373 May 27. On Maria of Portugal see Cantarell, Comas 2002, on the treaty ibidem, pp. 564-565.

${ }^{48}$ Cubells, Camarasa, Tamarit de Llitera, Vilanova de Meià and Sant Esteve [de la Sarga]. Fraga and Ballobar instead went to Peter IV. See ACA, C, reg. 1581, f. 126v [1], Barcelona, 1373 June 13 with the order to her treasurer Berenguer de Relat to pay the 10,000 florins destined for Maria of Portugal to the royal treasurer Pere Desvall. Several rents were sold to raise the amount of money, ACA, C, reg. 1581, f. 167v [1], Barcelona, 1373 August 31. 
Montgrí on his wife ${ }^{49}$. The occupation of the queenly domain by Castilian troops again was used to justify the donation, but once again, mention was made of rewarding Elionors merits. She received the right to appoint the Baiulus in each of the towns and the right to accommodate herself in the royal palace. At the same time, i.e. in July 1364, she was compensated with the castle of Sant Martí de Sobirats for her losses in the war against Castile ${ }^{50}$. The last donation for the queenly domain took place in May 1366, when Peter IV conferred anew Montblanc, Tàrrega and Vilagrassa as well as all other places which Henry of Trastámara had received from the Aragonese king: Castelló de la Plana, Ricla, Tamarit de Llitera and Vila-real are mentioned. In addition, the king guaranteed an administration according to the wishes of the queen granting her the right to appoint all officials freely and assuring the confirmation of her appointments ${ }^{51}$. Until the mid-1360s Elionor's patrimony continued thus to be enlarged, but the increment largely compensated for the previous losses in the course of the war. The inventory of her properties represents an ideal state, which was never achieved in reality, as Peter IV later confessed frankly.

Several aspects stand out in the described donations. Firstly, a certain number of towns and villages were given to the queen, which can be seen to have belonged to a queenly estate already established in the mid-fourteenth century $^{52}$. Further, the king adhered to the original marriage-treaty and compensated Elionor for the losses -or at least he tried to do so-. Also the towns used as bargaining chips in the negotiations with Henry of Trastámara were to be maintained in the queenly estate. Contractual fidelity was not the only factor which motivated the donations to Elionor -they were also used to express the king's gratitude to his wife-. The most important factor influencing the goods was the war against Castile. But already in the original dotation, the effects of the Plague can be found as cause for the modification of the queenly domain.

\section{REVISION OF THE ESTATE IN 1368 AND FURTHER MODIFICATIONS}

Despite the above-mentioned obvious difficulties during the war, the continuous modification of the queenly goods caused animosity towards Elionor. The changes led the fama publica to the assumption that the queen received and hoarded (thesauritzare) an excessive amount of money. This

${ }^{49}$ ACA, C, reg. 1537, f. 67v [1] = reg. 1536, f. 62v [1], Barcelona, 1364 July 31.

${ }^{50}$ ACA, C, reg. 1537, f. 78v [1] = reg. 1536, f. 69v [1], in loco de Olieto, 1364 October 21.

${ }^{51}$ ACA, C, reg. 1537, f. 86r [1] = reg. 1536, f. 78v [1], Calatayud, 1366 May 8.

${ }^{52}$ Jaspert 2015, pp. 103-104; Rodrigues, Santos 2010, p. 212; Ledesma 1979, pp. 138-139. 
opinion was apparently widely spread and was probably considered to be common knowledge ${ }^{53}$. In order to refute it, in 1368 King Peter established a committee consisting of his treasurer, Ramon de Vilanova, the escrivà de ració, Pere de Margens, and the lieutenant of the Mestre Racional, Bernat dez Coll. The investigation was to determine the actual level of queenly revenues and transfer an eventual surplus to the royal budget for free use ${ }^{54}$. Its results were presented in the council (in pleno consilio) and indeed ascertained a considerable increase in Elionor's income amounting to a raise of over fifty percent in comparison to the original dotation ${ }^{55}$.

On the other hand, the committee discovered that a great part of the goods -nearly half of them- had never actually been transferred to Elionor, and that she had never received any benefit from them. The reason was that Peter IV himself had given them away to other beneficiaries or sold them ${ }^{56}$. Among these places was Torroella de Montgrí, which had been sold by Elionor to Prince John's tutor, count John of Empúries -only one week after she had received it herself- ${ }^{57}$. Some of the newly donated possessions had never yielded any profit but rather required money for their maintenance ${ }^{58}$. Igualada had been destined for the sustentation of the royal chaplains ${ }^{59}$.

\footnotetext{
${ }^{53}$ On the fama publica see Wickham 2001, pp. 16, 21-22; Schubert 2001, pp. 117-118; Moos 1998, pp. 39-40. For the criteria for the fama publica, see Krötzl 1998, pp. 497-501.

${ }^{54} \mathrm{ACA}, \mathrm{C}$, reg. 1535 , f. 51r [1] = reg. 1536 , f. $81 \mathrm{v}$ [1] = reg. 1537, f. 95r [1] = reg. 1804, f. 86r [1], Barcelona, 1368 August 11; cited ACA, C, reg. 1536, f. 83r: "attendentes etiam nos pro eo quia datum erat nobis intelligi et ita fama publica refferebat quod redditus et iura locorum predictorum ascendebant ad immoderatam summam peccunie, quam vos annis singulis recondebatis et thesauritzabatis ad opus vestri, pro nunc ad cautelam recognosci et considerari fecisse per dilectum et fideles Raimundum de Villanova militem, thesaurarium, Petrum de Marginibus scriptorem portionis, Bernardum de Colle locumtenentem magistri racionalis et alios consiliarios nostros, presentibus Berengario de Relato thesaurario et quibusdam aliis consiliariis et domesticis vestris, dicte Regine, quos pro parte vestra ad hec vocare ex causa fecimus, ad quam quantitatem poterant ascendere et ascendebant redditus et iura civitatum, villarum et locorum predictorum in anno quocumque ad finem, ut, satisfacto vobis in iuribus vestris, residuum a vobis et vestris officialibus exigi faceremus illudque possemus convertere in necessitatibus nostris pro nostre libito voluntatis".

${ }^{55}$ A survey of the revenues is in ACA, C, reg. 1535, f. 56r-57v = reg. 1536, f. 86r-88v; see Appendix table 2.

${ }^{56}$ See Appendix table 3.

${ }^{57}$ ACA, C, perg., carp. 283, no. 2396, Barcelona, 1364 August 12. The same day she conferred the office of lieutenant, which she had held since 22 of January of 1364, to Ramon Berenguer, count of Empúries and father of the acquirer; ACA, C, reg. 1573, f. 68r [1]. An edition of Elionor's different lieutenancies is being prepared by the author.

${ }^{58}$ ACA, C, reg. 1536, f. 81v [1], see f. 83v: "civitatem et villas ac loca et castra de Albarrazino, de Oriola, de Callosa, de Guardamar, de Alacant, de Nonpot, que numquam vos possedistis neque possidetis neque eorum redditus sufficiunt ad retinentias castrorum suorum et custodiam eorundem immo in eis custodiendis habemus expendere de alia peccunia nostra".

${ }^{59} \mathrm{Ibidem}$, "villam de Agualada, cuius omnes redditus assignavimus cappellanis capelle palatii nostri regii Barchinone".
} 
Despite the above mentioned problems, Elionor's revenue amounted to 337,800 Barcelonese solidi. Its geographical provenance was very diverse; its greater part came from the kingdoms of Aragon and Valencia ${ }^{60} .200,000$ solidi originated from the ancient chamber (la sua cambra antiga). Another 70,000 solidi had been orally conferred by Peter IV to Elionor as additional payment for the maintenance of her court ${ }^{61}$. But the expenses had also increased significantly, explaining why a corresponding raise in income had become necessary. Two further items augmented the expenses: First, an annual payment of 25,000 solidi to the infanta Joanna ${ }^{62}$, and second, 10,000 solidi for the regular payment (quitacions) of the courtiers of her daughter-in-law María de Luna. Elionor also had to provide incomes for her daughter of the same name and Prince Martin, whose revenues were insufficient to maintain his own court. Additionally she had to cover extraordinary expenses for her own needs to maintain her status reginalis ${ }^{63}$. For this reason, Peter IV conceded the difference of 32,800 solidi and justified this increase of the queen's income, justifying this with the higher costs arising especially from the poor climatic conditions and the subsequent lack of provisions ${ }^{64}$. The use of the term status reginalis in this context clearly indicates a specific condition of the queen and her material status ${ }^{65}$.

During the remaining eight years of Elionor's reign the fluctuations of the goods slowed. First, Peter IV returned Tàrrega, which Felipe de Castro and his wife Joanna had received from count Henry of Trastámara for

${ }^{60}$ The data which Ulla Deibel gives are not entirely correct: for Valencia it is too high by the power of ten and for Aragon it does not take into account the exchange rate between the two currencies; Deibel 1928, p. 430. The fluctuating exchange rate was considered in the original calculations (ACA, C, reg. 1535, f. 57r: "Suma major d'açò a que pugen les dites rendes dels lochs damuntdits e d'aljames e altres drets, faent compte dels jaccenses cabals ab barchinonenses com uns anys ab altres cabals se cambien jaccenses ab barchinonenses"). A similar distribution of the revenues can be found in the income of Violant of Bar, but with a higher contribution from Catalonia; Ledesma 1979, p. 144. Sibil-la de Fortià received significantly lower revenues of 150,000 solidi, see Silleras 2010, p. 75; Roca 1928, pp. 29-30.

${ }^{61}$ ACA, C, reg. 1536, f. 81v [1], see f. 84r: "item pro emenda cessate provisionis victus, quam vobis et dominabus et domicellabus vestris in vestris et eorum victu ordinarie et continue facere habebamus, septuaginta mille solidos, prout inter nos et vos verbo fuit concordatum".

${ }^{62}$ ACA, C, reg. 1536, f. 48r [1], Barcelona, 1360 September 28; ibidem, 49v [1], Barcelona, 1360 October 16.

${ }^{63}$ ACA, C, reg. 1536, f. 82v [1], see f. 84v: "necnon habetis subire et supportare aliqua onera extraordinaria ultra ea que ordinaria sunt propter necessitatem persone vestre et alias ad que supportanda residui ducenti mille solidi non sufficiunt, etiam cum multo ampliori quantitate status reginalis vestri conditioni pensata".

${ }^{64}$ Ibidem, f. 84r: "faciente hoc malitia temporis et maxima penuria rerum et victualium predictorum, ut satis constat nobis et potest constare aliis quibuscumque".

${ }^{65}$ On this topic and the term estament reginal see Bratsch-Prince 2006, p. 18 for Violante of Bar; $c f$. also Jaspert 2015, p. 89. 
30.000 guilders $^{66}$. Elionor had to prosecute the case in the royal audiència arguing that the spouses possessed the town wrongfully. It must be assumed that the process was not fair, but rather that its outcome was already preconceived and served for the reconstitution of the Crown goods ${ }^{67}$. Further the royal couple exchanged the town of Sabadell and the castle of Arraona for the castle of Sant Martí Sarroca. This event is of special interest for the agency of a queen beyond her own estate. Elionor had acquired Sabadell and Arraona in a somewhat complicated transaction from Roger Bernat IV of Foix, viscount of Castellbó, for 154,000 Barcelonese solidi on 14 July $1366^{68}$. To raise this sum she sold Molins de Rei -which she had acquired only a short time before from the convent of the Poor Clares in Oristano- to her treasurer Berenguer de Relat ${ }^{69}$. The 85,500 solidi paid by him were balanced by order of the queen with the purchase price for Sabadell and Arraona ${ }^{70}$. Another 50,000 of the 154,000 solidi were contributed by the inhabitants of the two places. In exchange, they were to be exempt from taxes and only had to pay an annual rent of 2,000 solidi to Elionor ${ }^{71}$. One aspect of the bargain is especially interesting: Elionor promised the inhabitants that their towns would be in future inalienable from the crown. Yet, the terms which had been arranged by Berenguer de Relat as representative of the queen could not be directly implemented. This explains why Elionor promised that the conditions should, at the latest, be realized in her will ${ }^{72}$. The inhabitants were additionally guaranteed the right to pay

${ }^{66}$ On the marriage between Felipe de Castro and Joanna see Zurita 2007, lib. IX, cap. LXII, p. 540.

${ }^{67}$ ACA, C, reg. 1534, f. 130r [1], Barcelona, 1369 February 28. The decision was taken near the garden of the queenly palace in Barcelona, that is, "intus quandam logiam que est iuxta ortum seu viridarium palatii dicte domine Regine".

${ }^{68}$ Receipt of Roger de Basora as procurator of the viscount for the reception of the purchase price ACA, C, perg., carp. 285, no. 2463, Barcelona, 1366 July 9.

${ }^{69}$ Purchase of Molins de Rei ACA, C, perg., carp. 285, no. 2457, Zaragoza, 1366 June 8; sale to Berenguer de Relat ibidem, carp. 285, no. 2462, Zaragoza, 1366 July 2.

${ }^{70}$ ACA, C, perg., carp. 285, no. $2467=$ reg. 1574, f. 180r [1], Barcelona, 1366 July 30. Since the corresponding book of accounts of Berenguer de Relat is missing, a countercheck is impossible.

${ }^{71}$ ACA, C, reg. 1574, f. 86r [1], Zaragoza, 1366 July 2: "attendentes etiam vos, universitatem dictorum castri et ville et probos homines et singulares ipsius universitatis, cupientes ad manum nostre dominationis pervenire et sub nostro dominio gubernari et vivere, in predictis centum quinquaginta quatuor mille solidis dicti pretii de vestro proprio quinquaginta mille solidos dicte monete proffecto misisse, dedisse, solvisse et convertisse necnon dedisse et concessisse nobis et nostris perpetuo duos mille solidos Barchinonensium annuales et rendales pro questia ultra alios redditus predictorum castri et ville et terminorum suorum". The inhabitants raised the sum by selling several rents (censal mort) to different buyers from Barcelona, what Elionor confirmed for her part, ibidem, f. 124r [2], Barcelona, 1366 August 8.

${ }^{72}$ ACA, C, reg. 1574, f. 86r-v: "idcirco nos habentes ratum et gratum quicquid per dictum nostrum thesaurarium vobis promissum extitit super hoc, ut inferius continetur, serie presentis gratis et ex certa scientia et ex pacto predicto et bona fide convenimus et promittimus vobis et 
the remaining 104,000 solidi to Elionor in return for which they would be free from any oath. This stipulation would come into force as soon as the price had been paid ${ }^{73}$. In the end, the sovereign was to receive a rent of 2,000 solidi from Sabadell and Arraona but without paying a price for them. Peter IV complemented this purchase with the donation of the fountain Rossella, which was carried out at the end of $1366^{74}$. The interest which the inhabitants of the towns had in this deal was probably that of gaining a higher legal security, and, on a long-term basis, the reduction of taxes. Shortly after the purchase, Elionor confirmed all stipulations she had agreed within the purchase. Further, she confirmed all privileges and included a general pardon -excluding capital crimes which were to be sentenced with the death penalty-. She also obliged herself not to hinder the transfer of the places to the royal jurisdiction ${ }^{75}$. In this case, integration into the queenly estate proved to be an indirect but successful form of incorporation into the Crown ${ }^{76}$. It followed a typical pattern: the inhabitants contributed the required financial resources, at least partially, and received in exchange certain rights from the Crown, such as inalienability ${ }^{77}$. Thus, the case of Sabadell and Arraona was not particular, only that the queen was essential for the realization of the exchange and, especially, the establishment of the municipal privileges.

Elionor did not possess the two places for long, because the exchange with Sant Martí Sarroca was carried out in $1370^{78}$. She received this castle as free property (per proprium, liberum et franchum alodium). Additionally, she renounced two debts which Peter IV owed her since 1350 and 1366 respectively. The only condition stipulated from her part in the exchange

universitati castri et ville predictorum et terminorum suorum et vobis singularibus et probis hominibus ipsius universitatis et successoribus vestris perpetuo quod nos inter vivos seu in ultima voluntate nostra aut per viam seu modum cambii seu permutationis vel alias illis viis et modis, quibus melius expediens videbitur nobis, uniemus, adhunabimus et aggregabimus perpetuo vos et successores vestros et castrum et villam predicta cum omnibus terminis, iuribus et pertinentiis suis integriter, prout ea melius et plenius emimus, corone regie Aragonum et comitatui Barchinone, taliter et cum tali effectu quod inde nunquam coniunctim vel divisim aliquo casu ne aliquo iure, causa, ratione vel necessitate possitis abinde segregari vel etiam separari”.

${ }^{73}$ Ibidem, f. 87 r.

${ }^{74}$ Sabadell, Arxiu Municipal, perg., no. 713 = reg. 1537, f. 92v [1], Barcelona, 1366 December 28. Espuny 1988, p. 38 dates the concession to 1367 (without taking into account the Christmas style and without referencing the chancery-register, which is inexistent according to Espuny).

${ }^{75}$ ACA, C, reg. 1579, f. 82v [1], Barcelona, 1366 August 15 . The importance of this diploma is highlighted among other things by the use of the formula Ad eternam rei memoriam in the corroboration clause.

${ }^{76}$ On the similar case of the sale of Carrión to Catalina of Lancaster see Echevarría 2002, pp. 74-76.

${ }^{77}$ Ferrer i Mallol 1970-1971, pp. 394-399, 414-427, 449-450.

${ }^{78}$ ACA, C, reg. 1537, f. 111r [1] = reg. 1579, f. 144r [1], Barcelona, 1370 July 30. 
contract was the inalienability of Sabadell and Arraona. This clause is included twice in the contract emphasizing its importance to the queen. Although Peter IV issued another privilege in the same year confirming this right, its definitive implementation must be attributed to Elionor ${ }^{79}$. It was crucial for the consolidation of Sabadell as a municipal entity and as an extended marketplace ${ }^{80}$. The essential role of the queen in this exchange is apparent in the king's acceptance of the status quo: the sovereign linked the inalienability to the confirmation of all privileges which had been issued by his spouse, or by Berenguer de Relat as her procurator. Due to the strategic acquisition of Sant Martí Sarroca as personal property, Elionor was able to reduce the risk for her goods being affected by Peter's own politics.

The last assignment in favour of the queen's estate was Cocentaina in Valencia, coming to her from the possessions of Beatrix of Xèrica, who held the town in fief from Peter IV ${ }^{81}$. Apart from this increase, the queen's domain also lost one item. For the benefit of her daughter-in-law, Matha d'Armagnac, wife of Prince John, Elionor renounced her revenues from Berga and the Berguedà ${ }^{82}$. In the different marriage negotiations for the Infant, not only Berga, but also Montblanc and Torroella de Montgrí had been included as possible dowry ${ }^{83}$. In order to ensure the dotation of 100,000 Barcelonese solidi, Elionor assigned 20,000 solidi from the Jewish aljama of Calatayud to Prince John ${ }^{84}$. Despite these concessions, Matha complained to Peter IV about the infringement of her rights in Manresa as well as her insufficient endowment. The queen-to-be argued that she could not maintain her court with these revenues. Whether this is true or a dramatization, as Deibel assumes, cannot be clarified at this point ${ }^{85}$.

From 1368 until Elionor's death in 1375, the queenly estate neither increased substantially nor suffered great losses. A considerable expense at the benefit of her husband was the annual levy of 30,000 solidi which she started to

${ }^{79}$ ACA, C, reg. 920, f. 30r [1], Barcelona, 1370 August 20. Espuny 1988, pp. 39, 43 denies Elionor played a substantial role in the acquisition of the municipal autonomy. This opinion has to be rejected in view of the evidence of the sources. Further, Espuny dates the exchange to 1370 August 30 , ibidem, p. 43. This assertion must be modified, since it took place with the above mentioned act on 1370 July 30 .

${ }^{80}$ Argemí 2010,p. 76.

${ }^{81}$ ACA, C, reg. 1537, f. 126r [1], Barcelona, 1373 July 8.

82 ACA, C, reg. 1581, f. 121v [1] = reg. 1811, f. 124r [1], Barcelona, 1373 May 27; $c f$. Deibel 1928, p. 437 note 4 with reference to the second document (erroneously to f. 126r).

${ }_{83}$ Madurell 1934,pp. 9, 18, 21.

${ }^{84}$ ACA, C, reg. 1581, f. 130r [1] = reg. 1811, f. 126r [1], Barcelona, 1373 June 20. This donation was carried out in the course of the compensation of the infanta Maria of Portugal (see above), for which John had paid 20,000 Aragonese florins from the counter-dowry (dos) to his parents.

${ }_{85}$ Deibel 1928, p. 437. 
pay from 1 January 1369 . Yet, according to an oral agreement, the subsidies were to be paid already on 1 September 1368, that is, only half a month after Elionor's incomes were confirmed ${ }^{86}$. The formalization of the agreement was carried out roughly half a year later without mentioning reasons for the stipulation because it was not considered proper (quibusdam ex causis, quas exprimere non opportet). However, the document states that the sum should only be paid as long as the queen agreed (dum nobis placuerit). In addition, Elionor insisted on a receipt written by Peter IV himself ${ }^{87}$. Payment took place regularly during the following years ${ }^{88}$. In this way, Elionor contributed to the royal finances with a continuous payment that nearly equalised the rise of her revenues which had been agreed shortly before. The fact that Elionor would only accept receipts which had been written personally by the king indicates a certain precaution on her part, and is possibly a sign of alienation between him and her spouse.

After Elionor's death, her dowry was to return to the royal patrimony. Yet, this event was more complex, because she left several properties to Prince Martin as her universal heir which should have been returned to the king: Alcoi, the valley of Seta, Barxell, Xirillent, Gorga and Travadell originating in the inheritance of the countess of Terranova. Additionally, she left Llíria, which had been confirmed by Peter IV as free property. All those places could be re-acquired by the king or his heir as they were entitled (sicuti eis licet). But for this case Elionor stipulated the acquisition of rents in secure places in the kingdom of Valencia for the prince, which should amount to the same sum ${ }^{89}$.

\section{COOPERATION AND COMPETITION: ADMINISTRATION OF THE QUEENLY DOMAIN}

In what follows, this article shall consider the agency of the queen in administering her estate. As landlady, she controlled it and could, in principle, take all decisions autonomously ${ }^{90}$. In court, she officiated as the highest

${ }^{86}$ ACA, C, reg. 1577, f. 76r [1], Barcelona, 1369 May 22: "certis ex causis verbotenus anno quolibet per nos de peccunia curie nostre iussimus responderi".

${ }^{87}$ ACA, C, reg. 1577, f. 69v [1], Barcelona, 1369 April 10: "et recuperetis ab eo qualibet solutione, quam sibi feceritis, litteram seu litteras sua propria manu signatas seu albarana manu eius propria scripta et non alia ad cautelam". Later, this document -which should stay in the custody of Berenguer de Relat- was always used as reference for the establishment of the subsidy.

88 ACA, RP, MR, vol., Ser. Gen., 494, f. 52v [1], 104v [1]; 495, f. 72r [1], 87v [2], 92r [2], 99r [1], 101v [2]; 496, f. 64r [1]-[2], 70r [1], 83r [1]-[2], 97r [1], 103v [2]; 497, f. 63r [1] , 106v [3]; 498, f. 55v [3]; 499, f. 61r [2], 101r [1]; 500, f. 73v [1], 108r [1]; 501, f. 109r [2]; 503, f. 95r [4]; 504, f. 52v [2].

${ }^{89}$ ACA, C, reg. 1537, f. 139r [1], Barcelona, 1374 June 12, see f. 151v.

${ }^{90}$ In Castile, however, even the decisions in the queenly domain required approval of the king or, at least, they acquired a greater authority through his confirmation, Bianchini 2012 , p. 148. 
judge; she could also decide fiscal matters independently. Tax remissions in particular can be found quite frequently, due to the poor climatic conditions or damages caused by war. But the most direct influence could be exercised via appointment of officials. Additionally, by confirming the privileges of her predecessors, the queen became a link in a chain of royal landlords and landladies. In this way, she was integrated on a very essential level in the continuity of the monarchy. But the queenly domain shall not only be analysed from this internal point of view, but also with regard to the relations with other members of the royal family. As already mentioned in the case of Matha d'Armagnac, conflicts between members of the family could arise when their goods were affected. Those problems required a solution within the royal family.

One important aspect in the administration was the continuity of the rights in the domain, as expressed by the confirmations of privileges and personnel decisions. Several examples demonstrate Elionor's involvement in a wide range of affairs. She could issue confirmations of privileges autonomously without prior involvement of the king. For instance, she confirmed the Poor Clares of Calatayud an annual rent of eight fanecae salt and 500 solidi of Jaca originating from the saltworks of Piedra. Originally, these had been granted to the convent by king James II $^{91}$. Peter IV also confirmed the donations of his predecessors shortly after his accession to the throne ${ }^{92}$. The text of the three privileges is inserted in the confirmation granted by Elionor ${ }^{93}$. After her death, the king confirmed the rights partially, that is, the 500 solidi, following the diploma of his wife ${ }^{94}$. A new and at the same time final reference to the queenly privilege can be found in king John's I confirmation of the revenues, which was issued in the same year of his accession to the throne. All subsequent confirmations approved the rights without detailing the names of every predecessor ${ }^{95}$. In sum, the queen formed part of a continuous royal administration, although not all of the diplomas issued by her were relevant to later confirmations.

${ }_{91}$ The income from salt was donated on 9 August 1303, ed. López 1918, p. 182. The queen already seems to have been involved in this donation, since the order to issue was given by her chancellor. King James II granted the 500 solidi on 9 July 1325 (reg. 227, f. 199r [2], both issued in Calatayud).

92 ACA, C, reg. 860, f. 95r [3], València, 1336 December 4.

${ }_{93} \mathrm{AHN}$, Clero, carp. 3587, no. 14 (original) = ACA, C, reg. 1567, f. 158r [1], Zaragoza, 1360 January 19.

${ }^{94} \mathrm{AHN}$, Clero, carp. 3587, no. 15 (original) = ACA, C, reg. 928, f. 156v [1], Monzón, 1376 April 7.

${ }_{95}$ AHN, Clero, carp. 3587, no. 17 (original) = ACA, C, reg. 1891, f. 147v [1], Barcelona, 1387 May 12. John I confirmed also all titles to the convent without mentioning single predecessors by name, reg. 1890, f. 194r [1], Barcelona, 1387 May 15. 
Personnel decisions display the collaboration between the monarchs on a more practical level. The donation of the Muslim aljama of Eslida, mentioned by John Boswell, finally proved void, just as that of many other places. It is not exactly clear when the donation had taken place. However, the terminus ante quem is king Peter's mandate to the Muslims of Eslida from 31 March 1365, ordering that oaths of loyalty be given to his spouse in the presence of her procurator Guillem Colom ${ }^{96}$. Roughly half a year later Elionor released the Muslims of Eslida and Castro from their oath to her and ordered them to renew it to Bonaventura, wife of Pedro de Xèrica. At her petition, Peter IV had restituted Eslida ${ }^{97}$. Elionor's dominion over these places was only temporary and yet there is an interesting piece of evidence for administrative activities on her behalf in Eslida. Peter IV had granted Ivanyes Sebastià, rewarding his good services, a license vendendi vinum in eodem loco christianis ac etiam sarracenis ${ }^{98}$. At the petition of the recipient, Elionor confirmed the license and mentioned explicitly that she had received the place previously by royal donation ${ }^{99}$. The chronology of the two documents indicates that Eslida had already belonged to the queenly estate for three months. The fact that Ivanyes Sebastià strove for royal approval first, may be due to that it had been transferred to the queen only recently. Nevertheless a confirmation by the queen seemed necessary. This mechanism is even clearer in other cases, for instance in the confirmation of the alcait of the castle of Seta in Valencia. Before the castle was given to Elionor, Peter IV had bestowed this office on Pero San Pérez de Albarnella as gratification for his services. Later he requested that the queen confirm the nomination ${ }^{100}$.

But the administration was not always conducted harmonically, and sometimes led to conflict which could arise between all members of the royal family. Elionor and her son John engaged in litigation in 1370 over a fine arising from a court decision. This originated in a quarrel between the inhabitants of Tàrrega, which belonged to the queenly domain, and Granyena de Segarra, which formed part of the county of Cervera and therefore belonged to the Infant. Both Elionor and her son claimed the fine amounting to

96 Boswell 1977, p. 206 n. 43.

97 ACA, C, reg. 1573, f. 167r [1], Barcelona, 1365 October 10: "emperò, per tal com lo dit senyor Rey ara novellament a suplicació de la noble e amada dona Bonaventura, muller que fon del noble don Pedro de Exèrica ça enrera, la qual abans que-l Rey de Castella ne ses gents haguessen occupats los dits castells e lochs, aquells tenia e possehia per ses drets, ha provehit que ls dits castells e lochs sien restituyts e tornats a la dita dona". See also in this affair ibidem, f. $167 \mathrm{v}$ [1] to the "alcaydi et castellani" of the places in question.

98 ACA, C, reg. 1205, f. 87r [1], Almenara, 1365 May 6.

99 ACA, C, reg. 1573, f. 154r [1], Barcelona, 1365 July 14.

${ }^{100}$ ACA, C, reg. 983, f. 148r [1], Calatayud, 1359 February 8. 
2,500 Aragonese florins, but after hearing the counsellors from both sides, Peter IV decided in favour of Elionor and sentenced John to pay back the sum ${ }^{101}$. This was not the only dispute between the queen and her son. Three years later, the prince, or rather his officials, infringed upon her rights once more, this time in the Jewish aljamas of Valencia and Calatayud. In October 1373 the queen complained to John about excessive demands for accommodation for his officials and those of his spouse Matha d'Armagnac. Elionor informed him about a letter of Peter IV in which the king had sent him information about the usual contributions from the Jews. Further, she asked John to repay all excess funds and to punish insubordinate officials. Finally, she forbade any interference in the jurisdiction over the aljama such as some officials had planned according to her information ${ }^{102}$. One year later she had to appeal again to the Infant because he had again demanded money from her aljamas -this time 1,700 florins from Valencia and at least 1,000 florins from Calatayud, to which the Jews of Morvedre were to contribute 300 florins-. She prohibited her equerry and bailiff of Morvedre, Bonafonat de Sentfeliu, from forcing the Jews of Morvedre to pay the sum to her $\operatorname{son}^{103}$. Additionally, to prevent the extraction of money, Elionor forbade John to request money from the aljama of Morvedre or from any other aljama. She stressed her displeasure with the prince's actions and emphasized that the aljamas belonged to her domain emphasizing that John should demand nothing from these without her approval ${ }^{104}$. This command was repeated in the letter to the Infant himself as well in that to her bailiff. In the latter she also mentioned king Peter's displeasure with the situation ${ }^{105}$. This internal conflict in the heart of the royal family shows the queen in a relatively weak position faced with the aggressive and illegitimate assertions by her son. She had recourse to the authority of her husband to prevent John from interfering in her domain, or rather, to put

${ }^{01}$ ACA, C, reg. 1537, f. 108v [1], Montblanc, 1370 November 20.

${ }^{102}$ ACA, C, reg. 1582, f. 64v [1]; the letter of Peter IV reg. 1237, f. 38r [1], both sent Barcelona, 1373 October 3 . This service had been the subject of complaints from the Jews already in 1339, see Hinojosa 2007, p. 392.

${ }^{103}$ For València (including Morvedre) see ACA, C, reg. 1582, f. 106v [1] to Bonafonat de Sentfeliu and for Calatayud ibidem f. 106r [2] to the aljama of Calatayud, both Barcelona, 1374 October 27. For Bonafonat see Deibel 1928, pp. 405-406.

${ }_{104}$ ACA, C, reg. 1582, f. 106r [1], Barcelona, 1374 October 27: “car jaxí com ja desús és tocat a nós no plau ne volem que de les dites aljames ne d'altres dels lochs de la nostra cambra hajats res sens special consentiment nostre de nós abans obtengut", partially ed. Meyerson 2005 , p. 65 n. 43.

105 ACA, C, reg. 1582, f. 106v [1]: "la qual cosa no plau al senyor Rey ne a nós, segons que ja lo dit senyor e nós per altres letres fem saber largament al dit duch, car sab bé lo dit duch que les dites aljames són nostres e que nós havem d'aquelles subsidis e altres drets de què són asats carregats e no·ns plau que ell majorment axí sens voluntat nostra les opprima ne les carrech pus avant". 
an end to the incursions. At least partially, seems to have been impossible to settle these conflicts at an informal level. Rather they required a formal settlement involving the king as a higher legal authority.

Despite these frictions, mother and son collaborated in the administration. For instance, Elionor asked John to act as judge in Morella in a letter from March 1374. The case referred to Domingo Cubells and Johan Archayna who had been accused of different crimes. The first had spread rumours about the municipal government at the prince's court and caused unrest in the town. The latter had been accused among other things of counterfeiting and had been arrested by the Justicia of Morella. The Infant, however, had asked for his extradition. In the case of Domingo Cubells, Elionor requested that John conduct a careful investigation and pass sentence on the matter. According to the queen, this was necessary to protect the cosa pública, whose heads were the king and the prince, from malicious people ${ }^{106}$. She also demanded the restitution of Johan Archayna to the Justicia so that he might judge the case. In any case, the queen desired a punishment for the accused if they were found guilty because she wanted her city to be kept in good order ${ }^{107}$. Elionor's explicit attribution of the Infant as head of the government alongside his father is crucial in this letter. However, she asked for the cooperation of her son without renouncing her say in the case by demanding that the accused be handed over to the local authority.

Tensions between the royal couple arose over their goods, especially over the queen's revenues and their use in funding the war. The queen pawned her jewels and silverware several times in order to contribute to these expenses. Already at the beginning of the war, in April 1357, Peter IV asked his wife to provide 50,000 Barcelonese solidi in this way ${ }^{108}$. Several days later the king renewed his plea with more emphasis specifying that the recruitment of troops depended upon her financial contribution ${ }^{109}$. Direct resistance to these demands by Elionor cannot be proven, but the repeated letter with a more extensive justification points to reservations and hesitations on her part. Another letter, sent shortly thereafter, shows her opposition more clearly. Peter IV had to

106 ACA, C, reg. 1582, f. 85r [1], Barcelona, 1374 March 6: "si atrobats que-1 dit Domingo ha colpa que-l castigats, per tal manera (...) que la cosa pública, de què lo senyor Rey e vós sots caps, sia defesa de hòmens inichs e de males volentats".

107 Ibidem: "e de totes les dites coses vos pregam, per tal com nós tenim la dita vila e les rendes e drets de aquella entre les altres coses per cambra nostra e volem aquella vila ésser posada en bon estament".

${ }^{108}$ Coroleu 1889, p. 59. Elionor's letters from this time are not available since the majority of her Sigilli secreti registers are lost. Four volumes of this type are preserved which cover only approximately 15 percent of her reign.

${ }_{109}$ ACA, C, reg. 1150, f. 189v [1], Épila, 1357 April 30. 
appease his wife with regard to her tax income from the Jewish aljama of Teruel. He assured that the Jews would pay the normal taxes regardless of the special contribution of 10,000 solidi which he had requested from them, and asked for her cooperation by pawning her silver and jewels. Elionor had expressed her displeasure with Peter's tapping the resources of her aljama and also feared she would not be able to collect her complete incomes. King Peter countered by referring to his need and tried to dispel the objections by guaranteeing her revenues notwithstanding the circumstances of war ${ }^{110}$. Open opposition is not documented in the following years. Yet this did not mean the end to Royal initiatives to gain financial support from the queen. Once more, in 1361, Peter IV requested that Elionor contribute 100,000 solidi to pay the war expenses. One half was to be raised from her revenues of Teruel and the other half from pawning her jewellery. Furthermore, he asked her to send the sotstesorer, Guerau Sespluga, to the kingdom of Valencia in order to raise funds from the former possessions of Leonor of Castile. Again, the king tried to smooth the way for his demand by arguing that he preferred to turn to his spouse for support in a time of need rather than to other persons ${ }^{111}$. Even if Elionor's protest could not prevent the use of her goods to fund the war, Peter IV at least considered her opposition and acted more cautiously.

The restitution of Eslida and Castro to Bonaventura also demonstrates that the queen displayed at least passive resistance to the plans of her husband ${ }^{112}$. Elionor reacted in a similar manner in the case of the restitution of Montblanc, Tàrrega and Vilagrassa to count Henry of Trastámara. This measure had been decided by the Corts of Monzón but it could not be carried out without the approval of the queen. According to a mandate dated 20 December 1362, she agreed to the restitution at the petition of Peter IV out of love for him and appointed the royal secretary Jaume Conesa as procurator for the transfer of the towns to the count of Trastámara. She also released the inhabitants from their oath of loyalty ${ }^{113}$. De jure, as the mandate states, the transfer was not possible without the approval of the queen. Elionor may not have had a real choice in this case, however, and her only option was to consent to this fait accompli.

110 ACA, C, reg. 1150, f. 266r [1], Épila, 1357 May 2.

111 ACA, C, reg. 1335, f. 52v [2], Vallcanera (Ostal de la Bella Donna), 1361 August 26: "E d'açò us pregam que no prenats desplaser, car més nós amam plavir de vos que d'altre spacialment en aytal necessitat".

${ }^{112} C f$. ACA, C, reg. 1206, f. 114v [1], València, 1365 September 25.

113 ACA, C, reg. 1571, f. 72r [2], Monzón, 1362 December 20: "precibus et amore dicti domini Regis inducte". 


\section{CONCLUSIONS}

At the beginning of her reign, Elionor did not dispose of her own property but only of the goods from her dowry. Later her domain received other properties from four different sources. The major part came from the original endowment by Peter IV and was identical with the possessions of his former wives, Maria of Navarra and Leonor of Portugal. That the original dotation was understood in this way is indicated by the label cambra antiga applied in 1368. Those goods were handed down to subsequent queens and thus formed a basis for a queenly domain, comparable to the Casa da Rainha or Terras da Rainha in Portugal ${ }^{114}$. Further, the domain received possessions from the legacy of widows of previous kings, above all from Leonor of Castile, but also from Elisenda of Montcada. Those goods can be included in those of the aforementioned group. A third part came from the goods of rebels, that is, the possessions of Prince Ferran ${ }^{115}$. Finally, Elionor bought property that was partially included in the domain and partially in her private possessions, which she left to Prince Martin. During the acquisition of Sabadell and Arraona she favoured the incorporation of both settlements into the Crown, supporting a general tendency of the Catalonian cities and towns to seek royal protection -even though those privileges were frequently violated by the monarchs themselves- ${ }^{116}$. In her determination to achieve this goal, Elionor tried to strengthen the royal domain and thus showed considerable political foresight. The cases of Sabadell and Arraona were not isolated; as lieutenant, the queen tried to follow a similar political course concerning Crown possessions. Instead of selling them, she pawned them using the carta de gràcia. Elionor stipulated in such cases that, should the Crown repurchase the alienated goods, these should henceforward remain a royal possession. Whether she was acting as consort or as lieutenant, she pursued the same policy and tried to conserve the royal domain.

As outlined above, the development of the estate can be divided into three phases following its modifications: the first phase started with the dotation and ended with the expedition to Sardinia, from September 1349

114 Jaspert 2015, p. 104; Rodrigues 2005, pp. 143-145, 2007, p. 5; Rodrigues, Santos 2010, p. 212. The revenues from the towns in question were also of importance in other marriage negotiations: in the $15^{\text {th }}$ century, Fraga, Berga and Llíria served as pawn for the payment of the dowry of Leonor de Aragon, bride of Duarte of Portugal, see Rodrigues 2007, p. 5; Ledesma 1979, pp. 138-139.

115 Here can also be included the goods of local people living in the domain, which were sold on behalf of the queen. These, however, did not augment the domain but rather gave the queen a one-time financial benefit and therefore have not been treated in the present article.

116 Sabaté 2015, pp. 88-89. 
until May 1354. During this relatively peaceful time (at least the wars did not affect the Iberian kingdoms of the Crown of Aragon directly), the queen's possessions were relatively stable and were complemented only to guarantee the original amount of income. The second phase covers the period between 1358 and 1368. It is characterised above all by variations in the estate in consequence of the war against Castile, culminating in the revision of the queenly domain by a commission appointed by Peter IV, and the confirmation of the revenues. During the third phase from September 1368 until Elionor's death in 1375 , the domain was modified only a few times these changes however were substantial: the goods were concentrated in the kingdoms of Aragon and especially Valencia. The dominant position of these domains in the queenly estate was not initially apparent, but developed during the reign. The donation of goods was justified with different motives. First of all it must be pointed out that Peter IV showed a remarkable contractual fidelity -at least de jure-. The preservation of the initial endowment was used several times as a justification to compensate the queen with other goods. A second motive was gratitude for the birth of the successor to the throne, John. The same cause was later used as justification although the donation referred to Elionor's merits. Despite the increase after the marriage, its enlargement was by no means excessive ${ }^{117}$.

The king's reasons for modifying the queenly estate can similarly be divided into four different factors. First, at the beginning of Elionor's reign, the Plague diminished the revenues and led to the donation of other places. Climatic adversities were a further natural cause, which, like the Plague, did not diminish the domain itself but rather the revenues. The second factor is also a natural cause, albeit a personal one. Elionor was to return Biota and El Bayo to Peter IV after the birth of two sons ${ }^{118}$. This stipulation made the domain partially dependent upon a biological influence which could not be planned. Third, social, or rather, dynastic obligations affected the queenly domain, as demonstrated by the renunciation of Berga and the transfer of the income of the aljama of Calatayud to the Infant John for the endowment of his wife Matha d'Armagnac. Finally, political or military developments were the most important factor which affected the domain. Chief amongst these was the war against Castile, although this was no isolated case ${ }^{119}$.

117 As for instance in the case of Jeanne, spouse of Philipp V of France, see Brown 2000, pp. 138-152.

${ }^{118}$ See above part 2.

119 Orlando 2012, p. 125 about the reduction of the revenues of Constance of Aragón, wife of Frederick III [IV] of Sicily, in the course of the war with the Anjou. 
In principle, Elionor's goods and revenues were subject to strong fluctuations similar, for instance, to the modifications of the dowry of Eleanor of Provence, spouse of Henry III of England ${ }^{120}$. In contrast to this case, Elionor could at least dispose of the incomes and, additionally, she tried to resist efforts to reduce her possessions ${ }^{121}$. In addition to her own expenses, Elionor had to support other (female) members of the royal family as well as the king himself. The income confirmed in 1368 must therefore be considered as the maximum amount with which she was expected to cope with all her duties, that is, with which she had to maintain the status reginalis according to her social position. Thus, this sum included a buffer to compensate for possible losses. The great number of tax remissions issued during Elionor's reign demonstrates that such a buffer was necessary. The status reginalis was a serious criterion for the dotation of the queen although it could not be strained too much.

Regardless of the real stock of the domain, the queen could be subject to attacks, as shown by the examination of her goods in 1368, which remarkably referred to the fama publica. Although it is unclear which accusations had been made, they seemed to have been substantial -although the possibility remains that the reference to public opinion may have been used as a pretext by Peter IV to initiate this process-. If this term in the diploma is considered as an authentic expression, it highlights the precarious situation of the queen who could be delegitimised by public opinion ${ }^{122}$. Not even the exceptional circumstances during the war and the fact that Elionor acted as royal lieutenant who organised the military logistics could spare her the open discussion of her wealth ${ }^{123}$. Rather she stood under public observation ${ }^{124}$. However, the attacks did not necessarily arise from misogynous opposition, but should rather be understood as a concrete attack against a political person, aimed at weakening the base for Elionor's actions in form of her domain ${ }^{125}$. Besides, this case shows another function of the queen: she was supposed to act as moral example. An accumulation of excessive wealth was not befitting

${ }^{120}$ Howell 1987, pp. 382-383.

121 Ibidem pp. 380-381, 383, 390; Fößel 2005, p. 41.

${ }^{122}$ Wickham 2001, p. 26.

${ }^{123}$ Bernat Metge explicitly emphasizes in his panegyric poem Lo somni her role in the war as her most important merit; see Cingolani 2006, p. 242.

${ }^{124}$ For instance, the Corts of Monzón requested information about the revenues from King Peter IV and, additionally, from the queen and the Infants. Although he did not feel obligated to meet this demand, the king fulfilled it and ordered Berenguer de Relat (reg. 1180, f. 184v [2], Monzón, 1362 December 11: "e jassia que per ventura nós a açò no fóssem tenguts, emperò volem-los-en complaure en aquest cas") as well as the lieutenant of the Mestre Racional, Bernat dez Coll, and the royal treasurer to prepare a survey (ibidem, f. 184r [1], 184v [2], same date).

${ }^{125}$ On the political significance of rumours (fama), see Schubert 2001, pp. 119-122. 
to the image of the queen and this divergence from the norm was publicly attacked $^{126}$.

The queenly goods were used to help bear the war expenses, although not in the same measure as the royal domain, which was sold on a large scale to fund military activities. But because Elionor's domain served also as a bargaining chip for negotiations, its position is ambivalent. On one hand it served as a reserve fund that could be tapped when necessary to replenish a depleted treasury ${ }^{127}$ and, therefore, was always potentially at risk. But on the other hand, the queen's estate was seen as a better way to preserve goods for the heirs. This was not mere rhetoric, but a serious political goal since the domain was not put up for sale -rather its incomes were used or Elionor's jewellery was pawned- ${ }^{128}$. Hence, the preservation of the properties for the heirs appears to have enjoyed a high priority and the queen supported this objective by her own policy. Nevertheless, this principle was under severe strain due to the course of the war. This combination of competing pressures, and the ambiguous position of the queen as landlady, vassal and spouse, reveals an inherent tension in her position between dependence and autonomy.

The concrete administration of the domain displays a similar situation. As landholder, the queen was relatively independent and, at least de jure, an equal member in line with other royal landlords. Still, her position was not taken for granted, but she had to defend it, even against other members of the own dynasty. In this sense, Elionor's interaction with her husband and the Infant John was probably the most delicate task because it required a great deal of negotiation skills within the social construct which formed the royal family. Even though Elionor formally acknowledged her subordinate position to the king and his successor as head of the cosa publica, she actively influenced the discussions and decisions. While the relation between king and queen was essentially based upon negotiation, the queen enjoyed a considerable authority over her sons. However, it was not strong enough to clarify every situation that arose, so that the king had to mediate at times. Altogether, even in the administration of her own domain, queens were faced with a diversity of situations to which they had to adapt and react. If they wanted to pursue their very own interests and defend their rights even in face

\footnotetext{
${ }^{126}$ This criticism occurred also in similar cases in other realms, such as Eleanor of Castile, see Parsons 1998, pp. 74-75.

${ }^{127}$ Earenfight 2010a, p. 9; similarly, see Rodrigues, Santos 2010, p. 220. Baydal 2013, p. 51 assumes an explicit separation of the queen's possessions from the royal domain, at least in the case of Leonor of Castile.

${ }^{128}$ Perhaps for this reason the Infant Martin donated several goods to María de Luna, see Silleras 2008, p. 22.
} 
of adverse circumstances, considerable skills, the will to compromise and also a certain tenacity were required -skills which Elionor of Sicily possessed and was able to apply with considerable success-.

\section{BIBLIOGRAPHY}

Argemí Relat, Mercè (2010), D’Arraona a Sabadell. El naixement de la vila al voltant d'un mercat medieval (segles XI-XV), Sabadell, Amics de l'Art romànic de Sabadell.

Aurell, Martin (2002), Le douaire des comtesses catalanes de l'an mil, in Bougard, François (ed.), Dots et douaires dans le haut Moyen Âge, Rome, École française de Rome, pp. 171-188.

Baydal Sala, Vicent (2011), A figura de Francesc de Vinatea no reino de Valência. Da crônica real aos documentos arquivísticos (13311332), "Mirabilia" 13/2, pp. 214-237.

Baydal Sala, Vicent (2013), Els orígens de la revolta de la unió al regne de València (1330-1348), Valencia, Publicacions de la Universitat de València.

Bianchini, Janna (2012), The Queen's Hand. Power and Authority in the Reign of Berenguela of Castile, Philadelphia, University of Pennsylvania Press.

Boswell, John (1977), The Royal Treasure. Muslim Communities under the Crown of Aragon in the Fourteenth Century, New Haven (Conn.), Yale University Press.

Bratsch-Prince, Dawn (2006), The Politics of Self-Representation in the Letters of Violant de Bar (1365-1431), "Medieval Encounters" 12/1, pp. 2-25.

Brown, Elizabeth A. R. (2000), The King's Conundrum: endowing Queens and Loyal Servants, Ensuring Salvation, and Protecting the Patrimony in Fourteenth-Century France, in Burrow, John A. (ed.), Medieval Futures: attitudes to the Future in the Middle Ages, Woodbridge Suffolk, Boydell Press, pp. 115-165.

Cantarell Barella, Elena, Comas Via, Mireia (2002), Maria de Portugal, una dona amagada per la història, "Acta historica et archaeologica mediaevalia" 23-24, pp. 558-574.

Cingolani, Stefano (2006), Bernat Metge: lo somni, Barcelona, Barcino (Els nostres clàssics. Col·lecció B; 27).

Clay Stalls, William (1993), Queenship and Royal Patrimony in TwelfthCentury Iberia, in Vann, Theresa (ed.), Queens, Regents and Potentates, Dallas, Academia, pp. 49-61. 
Coroleu, Josep (1889), Documents historichs catalans del sigle XIV. Colecció de cartas familiars corresponents als regnats de Pere del Punyalet y Johan I, Barcelona, Imprempta la Renaixensa.

Deibel, Ulla (1928), La reyna Elionor de Sicilia, in Sobiranes de Catalunya. Recull de monografies històriques, "Memorias de la Real Academia de Buenas Letras de Barcelona" 10, pp. 349-453.

Earenfight, Theresa (2013), Queenship in Medieval Europe, New York, Palgrave Macmillan.

Earenfight, Theresa (2010a), Introduction, in Eadem (ed.), Women and Wealth in Late Medieval Europe, New York, Palgrave Macmillan, pp. 1-12.

Earenfight, Theresa (2010b), Royal Finances in the Reign of María of Castile. Queen-Lieutenant of the Crown of Aragon, 1432-53, in Eadem (ed.), Women and Wealth in Late Medieval Europe, New York, Palgrave Macmillan, pp. 229-244.

Echevarría, Ana María (2002), Catalina de Lancaster. Reina regente de Castilla (1372-1418), Hondarribia, Nerea.

Espuny i Tomàs, Maria Jesús (1988), Llibre de privilegis de la universitat de la vila i terme de Sabadell, Sabadell, Fundació Bosch i Cardellach.

Ferrer i Mallol, Maria Teresa (1970-1971), El patrimoni reial i la recuperació dels senyorius jurisdiccionals en els estats catalano-aragonesos a la fi del segle XIV, "Anuario de Estudios Medievales" 7, pp. 351-491.

Ferrer i Mallol, Maria Teresa (1988), La tinença a costum d'Espanya en els castells de la frontera meridional valenciana (segle XIV), "Miscel-lania de Textos Medieval" 4, pp. 1-102.

Fodale, Salvatore (2012), Un matrimonio al tempo della peste nera e della "pestifera sediciuni". Pietro il Cerimonioso, re d'Aragona, ed Eleonora di Sicilia (27 agosto 1349), in Giuffrida, Antonino; D'Avenia, Fabrizio; Palermo, Daniele (eds.), Studi storici dedicati a Orazio Cancila, Palermo, Mediterranea, pp. 35-64 (Quaderni Mediterranea; 16).

Fößel, Amalie (2005), The Queen's Wealth in the Middle Ages, "Majestas" 13, pp. 23-45.

Furió,Antoni; García-Oliver, Ferran (2007), Temps de dificultats (1348-1400), in Furió, Antoni (ed.), Història de la Corona d'Aragó, L'època medieval (1137-1479), Barcelona, Edicions 62, vol. I, pp. 245-286.

Gimeno Blay, Francisco et al. (2009), Ordinacions de la Casa i Cort de Pere el Cerimoniós, Valencia, Universitat de València (Fonts històriques valencianes; 39).

Hinojosa Montalvo, José (2007), En el nombre de Yahveh. La judería de Valencia en la Edad Media, Valencia, Ayuntamiento de Valencia (Colección Estudis; 23). 
Howell, Margaret (1987), The Resources of Eleanor of Provence as Queen Consort, "English Historical Review" 102, pp. 372-392.

Jaspert, Nikolas (2015), Indirekte und direkte Macht iberischer Königinnen im Mittelalter. ,Reginale “ Herrschaft, Verwaltung und Frömmigkeit, in Zey, Claudia (ed.), Mächtige Frauen? Königinnen und Fürstinnen im europäischen Mittelalter (11-14. Jahrhundert), "Vorträge und Forschungen" 81, pp. 73-130.

Krötzl, Christian (1998), Fama publica, fama sanctitatis. Zu Kommunikation und Information im Spätmittelalter, in Hamesse, Jacqueline (ed.), Roma, Magistra Mundi: itineraria Culturae Medievalis. Mélanges offerts au Père L.E. Boyle à l'occasion de son 75e anniversaire (Textes et Études de Moyen Âge, 10/1-3), Louvain-la-Neuve, Fédération Internationale des Instituts d'Études Médiévales, vol. 1, pp. 493-501. Lafuente Gómez, Mario (2012), Dos Coronas en guerra. Aragon y Castilla (1356-1366), Zaragoza, Grupo de Investigación Consolidado CEMA (Colección Mancuso; 6).

Ledesma Rubio, María Luisa (1979), El patrimonio real en Aragon a fines del siglo XV: los dominios y rentas de Violante de Bar, "Aragon en la Edad Media" 2, pp. 135-169.

López, Atanasio (1918), Monasterio de Santa Inés de Calatayud, "Archivo Ibero-Americano" 5/28, pp. 161-184.

Madurell i Marimon, Josep Maria (1934), Les noces de l'infant Joan amb Matha d'Armagnac, "Estudis Universitaris Catalans" 19, pp. 1-57.

Madurell i Marimon, Josep Maria (1971), Una concordia entre Pedro el Ceremonioso y María de Portugal, "Anuario de Historia del Derecho Español" 41, pp. 425-438.

Meyerson, Mark (2005), Defending their Jewish Subjects. Elionor of Sicily, Maria de Luna and the Jews of Morvedre, in Earenfight, Theresa (ed.), Queenship and Political Power in Medieval and Early Modern Spain, Aldershot, Ashgate, pp. 55-77.

Moos, Peter von (1998), Das Öffentliche und das Private im Mittelalter. Für einen kontrollierten Anachronismus, in Melville, Gert (ed.), Das Öffentliche und das Private in der Vormoderne, Köln - Weimar Wien, Böhlau, pp. 3-83.

Orlando, Caterina (2012), Una città per le regine. Istituzioni e società a Siracusa tra XIII e XV secolo, Caltanissetta - Roma, Salvatore Sciascia Editore (Medioevo Mediterraneo; 5).

Parsons, John Carmi (1998), Eleanor of Castile. Queen and Society in Thirteenth-Century England, New York, St. Martin's Press.

Recuero Lista, Alejandra (2013), Doña Leonor: infanta castellana, reina aragonesa y elemento de discordia en las relaciones castellano- 
aragonesas en la primera mitad del siglo XIV, "Estudios Medievales Hispánicos” 2, pp. 221-240.

Roca, Josep Maria (1928), La reyna empordanesa, in Sobiranes de Catalunya. Recull de monografies històriques, "Memorias de la Real Academia de Buenas Letras de Barcelona" 10, pp. 10-209.

Rodrigues, Ana Maria S.A. (2005), The Queen Consort in Late-Medieval Portugal, in Bolton, Brenda; Meek, Christine (eds.), Aspects of power and authority in the Middle Ages, Turnhout, Brepols, pp. 131-145.

Rodrigues, Ana Maria S.A. (2007), For the Honor of Her Lineage and Body: the Dowers and Dowries of Some Late Medieval Queens of Portugal, "E-Journal of Portuguese History" 5, http://www.brown. edu/Departments/Portuguese_Brazilian_Studies/ejph/html/issue9/ pdf/arodrigues.pdf [accessed: 21/03/2014].

Rodrigues, Ana Maria S.A.; Santos Silva, Manuela (2010), Private Properties, Seigniorial Tributes, and Jurisdictional Rents: the Income of the Queens of Portugal in the Late Middle Ages, in Earenfight, Theresa (ed.), Women and Wealth in Late Medieval Europe, New York, Palgrave Macmillan, pp. 209-228.

Sabaté, Flocel (2015), El temps de Francesc Eiximenis. Les estructures econòmiques, socials i polítiques de la Corona d'Aragó a la segona meitat del segle XIV, in Riera i Melis, Antoni (ed.), Francesc Eiximenis (c. 1330-1409): el context i l'obra d'un gran pensador català medieval, Barcelona, Institut d'Estudis Catalans, pp. 80-166.

Sánchez Martínez, Manuel (2005), Negociación y fiscalidad en Cataluña a mediados del siglo XIV, in Ferrer i Mallol, Maria Teresa; Moeglin, Jean-Marie; Péquignot, Stéphane et al. (eds.), Negociar en la Edad Media/Negocier au Moyen Âge, Barcelona, Consejo Superior de Investigaciones Científicas, pp. 123-164.

Schubert, Ernst (2001), Erscheinungsformen der öffentlichen Meinung im Mittelalter, "Das Mittelalter" 6/1, pp. 109-127.

Silleras Fernández, Núria (2010), Money Isn't Everything: Concubinage, Class, and the Rise and Fall of Sibil.la de Fortià, Queen of Aragon (1377-1387), in Earenfight, Theresa (ed.), Women and Wealth in Late Medieval Europe, New York, Palgrave Macmillan, pp. 67-88.

Silleras Fernández, Núria (2008), Power, Piety, and Patronage in Late Medieval Queenship: Maria de Luna, New York, Palgrave Macmillan.

Soldevila, Ferran (1963), Història de Catalunya, Barcelona, Alpha.

Vilar, Pierre (2001), Crecimiento y desarrollo. Economía e historia: reflexiones sobre el caso español, Barcelona, Crítica.

Wickham, Chris (2001), Fama and the Law in Twelfth-Century Tuscany, in Fenster, Thelma; Smail, Daniel Lord (eds.), Fama. The Politics of 
Talk \& Reputation in Medieval Europe, Ithaca-London, Cornell University Press, pp. 15-26.

Zeldes, Nadia (2004), The Queen's Property. Isabel I and the Jews and Converts of the Sicilian Camera Reginale after the 1492 Expulsion, "Hispania Judaica Bulletin" 4, pp. 70-85.

Zurita, Jerónimo (2007), Anales de la Corona de Aragon, ed. Ángel Canellas López, Zaragoza, Institución Fernando el Católico. 


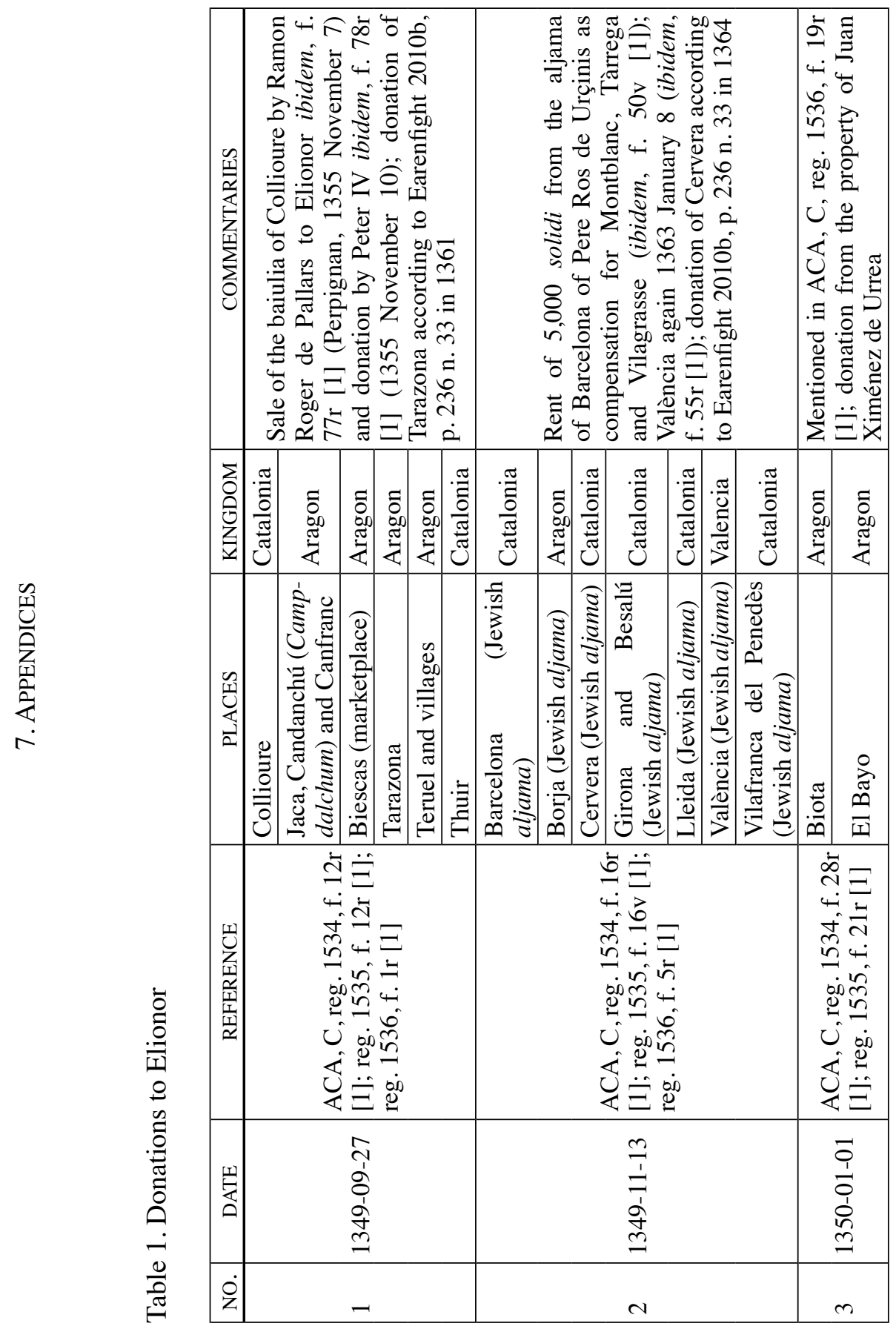




\begin{tabular}{|c|c|c|c|c|c|c|c|c|c|c|c|c|c|c|c|}
\hline \multirow{2}{*}{ 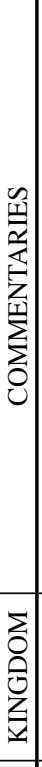 } & & & & & \multicolumn{5}{|c|}{ 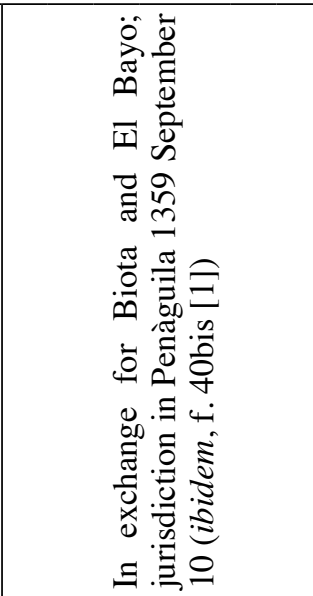 } & 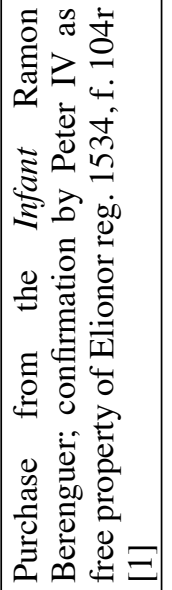 & \multicolumn{5}{|c|}{ 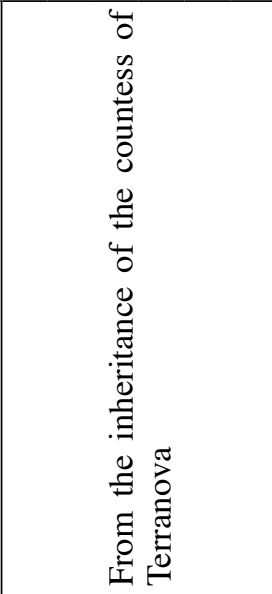 } \\
\hline & 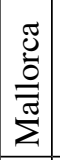 & $\frac{\tilde{e}}{\stackrel{0}{0}}$ & 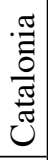 & $\frac{\cdot \frac{\pi}{\Xi}}{\frac{\tilde{\sigma}}{\tilde{E}}}$ & $\mid \begin{array}{c}\frac{\pi}{0} \\
\frac{0}{0} \\
\frac{\pi}{\pi}\end{array}$ & $\begin{array}{l}\frac{\pi}{0} \\
\frac{0}{0} \\
\frac{\pi}{\pi}\end{array}$ & \begin{tabular}{l|l}
$\frac{\pi}{0}$ & $\cdot \frac{\pi}{0}$ \\
$\frac{0}{0}$ & $\frac{0}{0}$ \\
$\frac{\pi}{\pi}$ & $\frac{\pi}{\pi}$ \\
&
\end{tabular} & 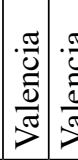 & \begin{tabular}{l|l}
$\frac{\pi}{U}$ & $\cdot \frac{\pi}{0}$ \\
$\frac{\pi}{0}$ & $\frac{\pi}{0}$ \\
$\frac{\pi}{\pi}$ & $\frac{\pi}{\pi}$
\end{tabular} & $\begin{array}{l}\frac{\pi}{0} \\
\frac{0}{0} \\
\frac{\pi}{\pi}\end{array}$ & $\frac{\frac{\pi}{3}}{\frac{\pi}{0}} \frac{\frac{\pi}{3}}{\frac{\pi}{2}}$ & 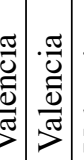 & 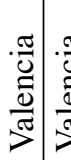 & \begin{tabular}{l|l}
$\frac{\pi}{3}$ & $\frac{\pi}{3}$ \\
$\frac{\pi}{2}$ & $\frac{\pi}{2}$ \\
$\frac{\pi}{\pi}$ &
\end{tabular} & \\
\hline 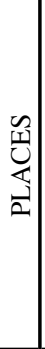 & $\begin{array}{l}\tilde{\sigma} \\
\dot{n} \\
i \\
\dot{\Delta}\end{array}$ & 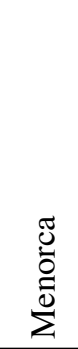 & 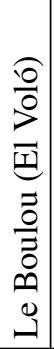 & 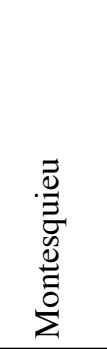 & 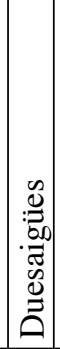 & 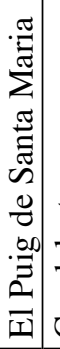 & 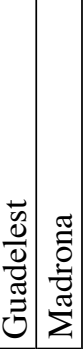 & 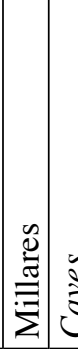 & 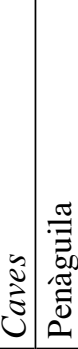 & $\begin{array}{l}\stackrel{\Xi}{\Xi} \\
\stackrel{\Xi}{\Xi}\end{array}$ & 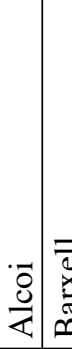 & 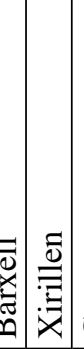 & \begin{tabular}{l} 
\\
\multirow{2}{*}{}
\end{tabular} & 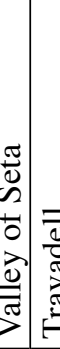 & \\
\hline 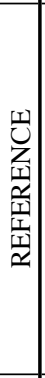 & 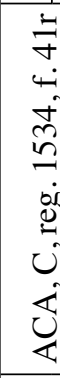 & 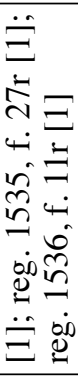 & & 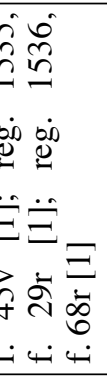 & & & 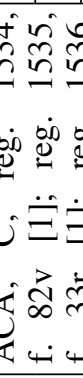 & 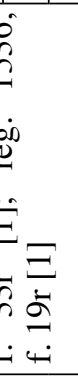 & & 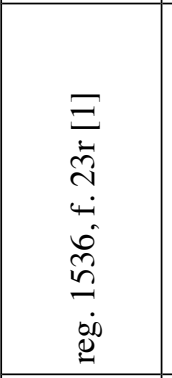 & & 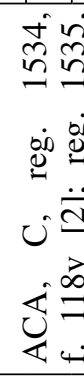 & 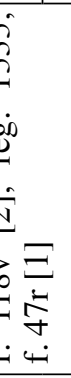 & & \\
\hline 空 & & $\begin{array}{l}\infty \\
1 \\
\vdots \\
1 \\
0 \\
n \\
n\end{array}$ & & $\begin{array}{l}0 \\
0 \\
0 \\
0 \\
1 \\
n \\
0\end{array}$ & & & 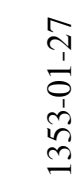 & & & 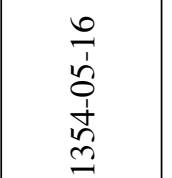 & & 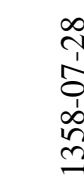 & $\begin{array}{l}0 \\
\vdots \\
1 \\
\vdots \\
\vdots \\
0 \\
0 \\
0\end{array}$ & & \\
\hline & & $\nabla$ & & $n$ & & & 0 & & & $r$ & & $\infty$ & & & \\
\hline
\end{tabular}




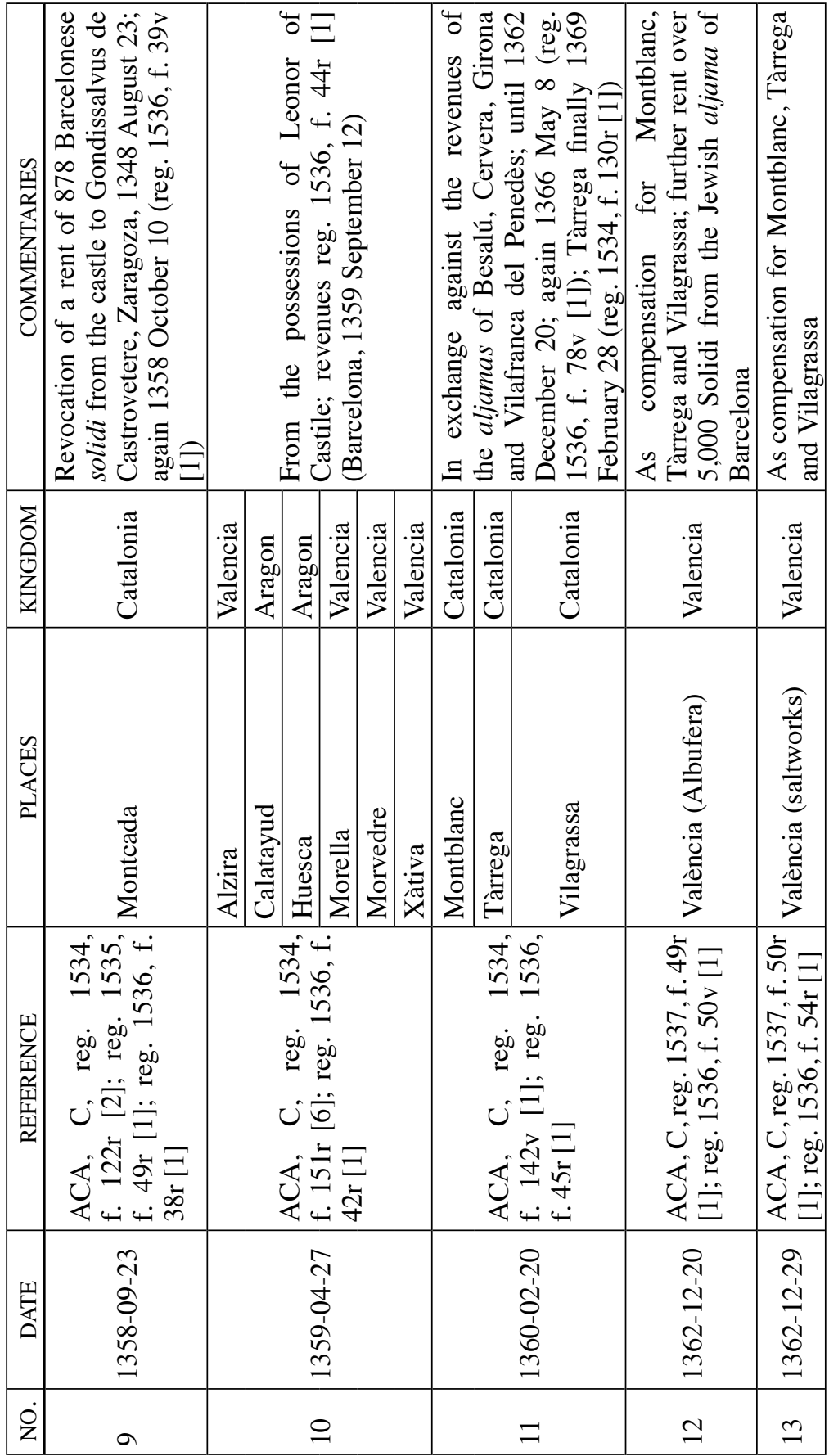

ANUARIO DE Estudios Medievales, 46/1, enero-junio 2016, pp. 231-268

ISSN 0066-5061, doi:10.3989/aem.2016.46.1.07 


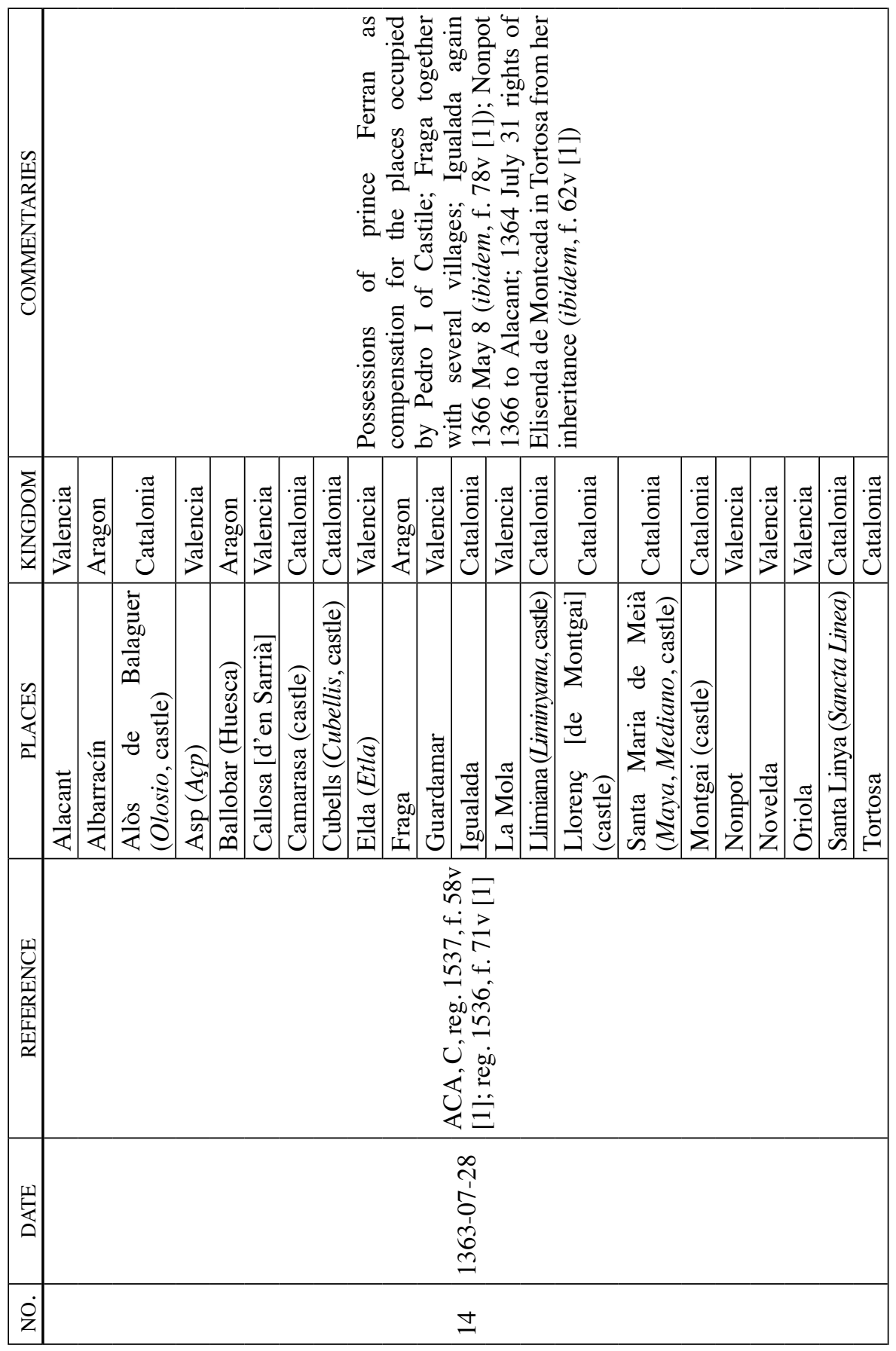




\begin{tabular}{|c|c|c|c|c|c|c|c|c|c|c|c|}
\hline 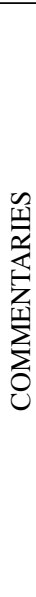 & & & & & 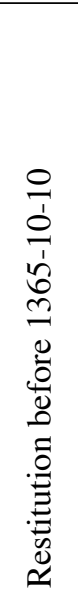 & \multicolumn{4}{|c|}{ 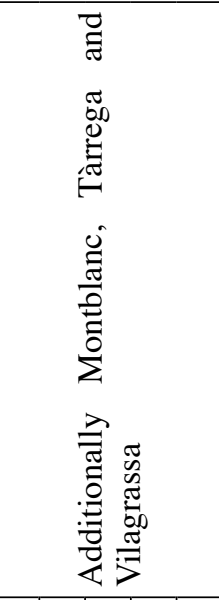 } & 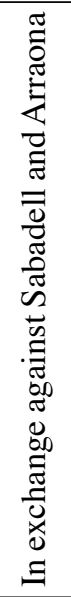 & \\
\hline $\begin{array}{l}\sum \\
0 \\
0 \\
\text { Z } \\
\end{array}$ & 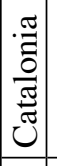 & . & 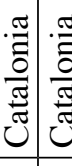 & 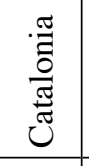 & $\frac{j}{\frac{\pi}{0}}$ & 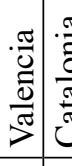 & 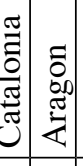 & 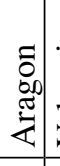 & $\begin{array}{l}\frac{\pi}{0} \\
\frac{\pi}{0} \\
\frac{\pi}{7}\end{array}$ & 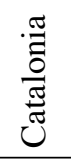 & 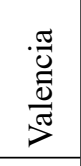 \\
\hline 坞 & 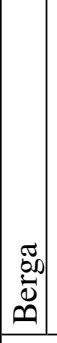 & 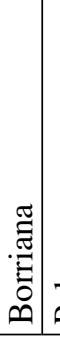 & 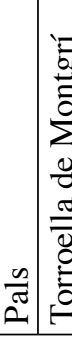 & 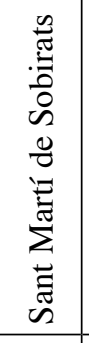 & 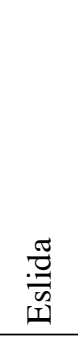 & 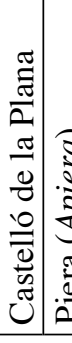 & 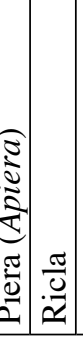 & 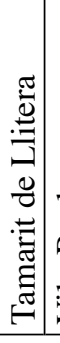 & 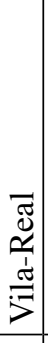 & 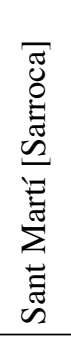 & 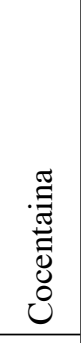 \\
\hline 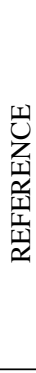 & & 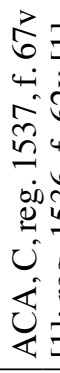 & 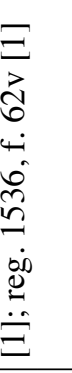 & 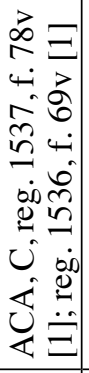 & 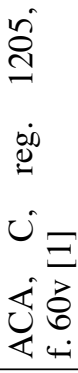 & & 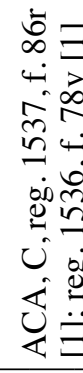 & & & 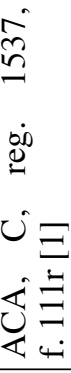 & 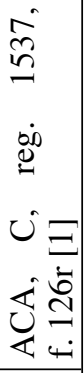 \\
\hline 戛 & & $\begin{array}{l}\vec{r} \\
\dot{1} \\
\dot{1} \\
\dot{d} \\
-\end{array}$ & 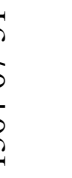 & $\begin{array}{l}\vec{T} \\
0 \\
\vdots \\
\dot{J} \\
\stackrel{0}{\ddots}\end{array}$ & 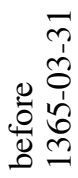 & & $\begin{array}{l}\infty \\
0 \\
1 \\
0 \\
1 \\
1 \\
0 \\
0 \\
n\end{array}$ & & & 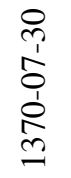 & $\begin{array}{l}\infty \\
0 \\
1 \\
0 \\
1 \\
\infty \\
0 \\
n\end{array}$ \\
\hline $\mathrm{z}$ & & $\stackrel{n}{n}$ & & $\underline{-}$ & 그 & & $\infty$ & & & 9 & 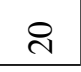 \\
\hline
\end{tabular}

ANUARIO DE Estudios MEdieVAles, 46/1, enero-junio 2016, pp. 231-268 ISSN 0066-5061, doi:10.3989/aem.2016.46.1.07 
Table 2. Revenues of Elionor in August 1368

\begin{tabular}{|c|c|}
\hline PLACE & REVENUE \\
\hline \multicolumn{2}{|l|}{ Aragon } \\
\hline $\begin{array}{l}\text { Jaca, Candanchú } \\
\text { (Campdalchum) } \\
\text { and Canfranc }\end{array}$ & 9,000 s. J. \\
\hline $\begin{array}{l}\text { Teruel and } \\
\text { villages }\end{array}$ & 40,000 s.J. \\
\hline Calatayud & 35,000 s. J. \\
\hline Huesca & 12,000 s. J. \\
\hline Tarazona & 1,000 s.J. \\
\hline Sum Aragon & 97,000 s. J. \\
\hline \multicolumn{2}{|l|}{ Valencia } \\
\hline $\begin{array}{l}\text { València (Jewish } \\
\text { aljama) }\end{array}$ & 12,000 s. B. \\
\hline El Puig & 2,000 s. B. \\
\hline Penàguila & 1,000 s. B. \\
\hline Xàtiva & 30,000 s. B. \\
\hline Alzira & $21,500 \mathrm{s.} B$. \\
\hline Morvedre & 16,000 s. $B$. \\
\hline Morella & 42,000 s. B. \\
\hline $\begin{array}{l}\text { València } \\
\text { (albufera) }\end{array}$ & 16,000 s. $B$. \\
\hline $\begin{array}{l}\text { València } \\
\text { (saltworks) }\end{array}$ & 7,000 s. B. \\
\hline Borriana & 3,000 s. B. \\
\hline Sum Valencia & 150,500 s. B. \\
\hline
\end{tabular}

\begin{tabular}{|c|c|}
\hline PLACE & REVENUE \\
\hline \multicolumn{2}{|l|}{ Catalonia } \\
\hline Collioure & 35,000 s. $B$. \\
\hline Thuir & 6,000 s. $B$ \\
\hline $\begin{array}{l}\text { Barcelona } \\
\text { (Jewish aljama) }\end{array}$ & 13,000 s. B. \\
\hline $\begin{array}{l}\text { Le Boulou (El } \\
\text { Voló) }\end{array}$ & 7,000 s. B. \\
\hline Montcada & 800 s. B. \\
\hline Montesquiu, & 2,000 s. B. \\
\hline $\begin{array}{l}\text { Lleida (Jewish } \\
\text { aljama) }\end{array}$ & 3,000 s. B. \\
\hline Montblanc & 1,000 s. B. \\
\hline Vilagrassa & 4,000 s. B. \\
\hline Tortosa & 6,000 s. B. \\
\hline Sum Catalonia & 77,800 s. $B$. \\
\hline \multicolumn{2}{|l|}{ Mallorca } \\
\hline Menorca & 20,000 s. B. \\
\hline Eivissa & 1,000 s. B. \\
\hline Sum Mallorca & 21,000 s. $B$. \\
\hline Total sum & 337,800 s. $B$. \\
\hline
\end{tabular}

(*) s. J. = solidi of Jaca; s. B. = solidi of Barcelona. 
Table 3. Alienated goods

\begin{tabular}{|c|c|c|c|}
\hline NO. & PLACE & KINGDOM & BENEFICIARY \\
\hline 1 & Borja (Jewish aljama) & Aragon & Bertrand du Guesclin \\
\hline 2 & Tàrrega & Catalonia & $\begin{array}{l}\text { Filipus de Castro for the count of } \\
\text { Trastámara }\end{array}$ \\
\hline 3 & Pals & Catalonia & Gilabertus de Caudillis \\
\hline 4 & Ricla & Aragon & Gondissalvus Gonsalez de Lusia \\
\hline \multirow{2}{*}{5} & Berga & Catalonia & \multirow{2}{*}{ Count John d’Empúries } \\
\hline & Torroella de Montgrí & Catalonia & \\
\hline \multirow{11}{*}{6} & Alòs & Catalonia & \multirow{11}{*}{ Count of Dénia } \\
\hline & Ballobar & Aragon & \\
\hline & Camarasa & Catalonia & \\
\hline & Cubells & Catalonia & \\
\hline & Fraga and villages & Aragon & \\
\hline & Guadelest & Valencia & \\
\hline & Llimiana & Catalonia & \\
\hline & Llorenç & Catalonia & \\
\hline & Meià & Catalonia & \\
\hline & Montgai & Catalonia & \\
\hline & Santa Linya & Catalonia & \\
\hline \multirow{3}{*}{7} & Asp & Valencia & \multirow{3}{*}{$\begin{array}{l}\text { Hugh of Calveley (Hugo de } \\
\text { Cavarlay) }\end{array}$} \\
\hline & Elda & Valencia & \\
\hline & La Mola & Valencia & \\
\hline \multirow{6}{*}{8} & Besalú (Jewish aljama) & Catalonia & \multirow{6}{*}{ Infant John } \\
\hline & Castelló de la Plana & Valencia & \\
\hline & Cervera (Jewish aljama) & Catalonia & \\
\hline & Girona (Jewish aljama) & Catalonia & \\
\hline & $\begin{array}{l}\text { Vilafranca del Penedès (Jewish } \\
\text { aljama) }\end{array}$ & Catalonia & \\
\hline & Vila-real & Valencia & \\
\hline 9 & Novelda & Valencia & $\begin{array}{l}\text { Matthew Gournay (Mahi de } \\
\text { Gornay) }\end{array}$ \\
\hline 10 & Tamarit de Llitera & Aragon & $\begin{array}{l}\text { Maria of Portugal, widow of } \\
\text { prince Ferran }\end{array}$ \\
\hline 11 & Madrona & Valencia & Mateu Mercer \\
\hline 12 & Piera & Catalonia & Pere Jordà d'Urries \\
\hline
\end{tabular}

Fecha de recepción del artículo: mayo 2015

Fecha de aceptación y versión final: febrero 2016 